IZA DP No. 9636

Does Joining the EU Make You Happy?

Evidence from Bulgaria and Romania

Milena Nikolova

Boris Nikolaev

January 2016 


\title{
Does Joining the EU Make You Happy? Evidence from Bulgaria and Romania
}

\author{
Milena Nikolova \\ IZA and Brookings Institution \\ Boris Nikolaev \\ Oxford College of Emory University
}

Discussion Paper No. 9636

January 2016

IZA

P.O. Box 7240

53072 Bonn

Germany

Phone: +49-228-3894-0

Fax: +49-228-3894-180

E-mail: iza@iza.org

\begin{abstract}
Any opinions expressed here are those of the author(s) and not those of IZA. Research published in this series may include views on policy, but the institute itself takes no institutional policy positions. The IZA research network is committed to the IZA Guiding Principles of Research Integrity.

The Institute for the Study of Labor (IZA) in Bonn is a local and virtual international research center and a place of communication between science, politics and business. IZA is an independent nonprofit organization supported by Deutsche Post Foundation. The center is associated with the University of Bonn and offers a stimulating research environment through its international network, workshops and conferences, data service, project support, research visits and doctoral program. IZA engages in (i) original and internationally competitive research in all fields of labor economics, (ii) development of policy concepts, and (iii) dissemination of research results and concepts to the interested public.
\end{abstract}

IZA Discussion Papers often represent preliminary work and are circulated to encourage discussion. Citation of such a paper should account for its provisional character. A revised version may be available directly from the author. 


\title{
ABSTRACT
}

\section{Does Joining the EU Make You Happy? Evidence from Bulgaria and Romania*}

\begin{abstract}
We examine the effect of joining the European Union on individual life satisfaction in Bulgaria and Romania in the context of the 2007 EU enlargement. Although EU membership is among the most important events in Bulgaria and Romania's modern histories, there is no evidence on how it affected the subjective well-being of ordinary people in the two countries. Using a difference-in-differences strategy and Eurobarometer data, we provide the first evidence that joining the EU increased average life satisfaction in Bulgaria and had a positive but statistically insignificant effect in Romania. One explanation is that trust towards the EU increased only in Bulgaria but not in Romania after both countries joined in 2007. Furthermore, Romania's political war of 2007 may have mired the country's positive life satisfaction experiences related to EU membership. We also show that the younger, the employed, and those with a high-school education were the winners from EU integration. Our results are robust to two placebo tests, in which we use two fake entry dates to the EU, and to an estimation using bootstrapped standard errors. Our findings have implications for EU integration policy and future enlargements.
\end{abstract}

JEL Classification: $\quad$ I31, I39, P20

Keywords: $\quad$ subjective well-being, happiness, transition economies, EU enlargement, difference-in-differences, European Union

Corresponding author:

Milena Nikolova

IZA

Schaumburg-Lippe-Str. 5-9

53113 Bonn

Germany

E-mail: nikolova@iza.org

\footnotetext{
* The authors would like to thank Carol Graham, Monica Roman, Madiha Afzal, Peter Murrell, Cliff Gaddy, and Dave Crocker, as well as IZA Reading Group participants for helpful comments and suggestions. A preliminary version of the paper was entitled "Does Joining the EU Make You Happy? Evidence from Central and Eastern Europe" and appeared as a chapter in Milena Nikolova's dissertation written at the University of Maryland, College Park.
} 


\section{Introduction}

On January $1^{\text {st }}, 2007$, Bulgaria and Romania (EU-2) joined the European Union. Huge celebrations in both countries marked what the Romanian president at the time, Traian Basescu, called the "road of our future ... the road of our happiness." Perhaps to reinforce his words, the European flag was raised outside of the government headquarters in Bucharest to the European anthem, Beethoven's Ode to Joy. In Sofia, Bulgaria's capital, tens of thousands of people celebrated beneath a shower of fireworks that filled the sky over the Battenberg Square where the old Communist party was once headquartered. In an emotional speech to the nation, Georgi Parvanov, the Bulgarian president at the time, called the event "among the most important in [Bulgaria's] national history."

Since the mid-1990s, the prospect of joining the European Union (EU) has shaped the socio-economic and political transformations in the post-socialist countries in Central and Eastern Europe (CEE) and the former Soviet Union (FSU). Between 2004 and 2007, ten CEE and Baltic countries (EU-10) joined the European Union, which was arguably the culmination of their transition processes. ${ }^{1} \mathrm{EU}$ membership symbolized the "return to Europe" and an "enormous chance for new generations," as the then Romanian president Basescu described the end of a long and painful 17-year transition process. It re-established "the standard of a normal society," open markets, democratic institutions, and a horizon of new opportunities ( $\AA$ slund, 2007, p. 7).

But how did this "heavenly event," as the Bulgarian president Parvanov called it on the day of joining, affect the subjective well-being (SWB) of ordinary Bulgarians and Romanians? Did EU membership improve people's life satisfaction as they were now part of the largest economy in the world and were able to travel, study, work, invest, and even retire in the EU? Or did Bulgarians and Romanians become less satisfied with life amidst a long list of membership requirements and restrictions that left many feeling as "second-class" citizens compared to other European members? While EU membership has generally had a positive impact on the macroeconomic and institutional outlooks in transition countries, and the EU-10 in particular, the effects on individual SWB remain largely unexplored.

1 The EU-8 countries are the Czech Republic, Estonia, Hungary, Latvia, Lithuania, Poland, Slovenia, and Slovakia. The EU-2 countries are Bulgaria and Romania, which joined in 2007. Croatia joined the EU in July 2013 but is excluded from this analysis due to limited post-membership data. As explained in Section 3, it is instead used as the counterfactual. 
To our knowledge, we are the first study to estimate the impact of European integration on the life satisfaction of Bulgarians and Romanians (EU-2). Our research questions are policy-relevant and build on the extant literature in several ways. First, understanding the well-being effects of EU integration is especially important as the EU prepares for another round of memberships. With the exception of Turkey, the next countries waiting to join-Albania, former Yugoslav Republic of Macedonia, Montenegro, Serbia, Kosovo, and Bosnia and Herzegovina-are CEE countries and have similar historical and politico-economic backgrounds as Bulgaria and Romania. The EU-2 experiences can therefore guide the expectations of policymakers in these countries about the well-being consequences of EU membership. Second, according to the Treaty of Lisbon, one of the EU's main goals is to promote the well-being of its citizens (EU, 2007), which implies well-being in both its material and non-material life domains. Yet, the EU-2 countries face convergence challenges as they are generally poorer and unhappier compared to their EU-15 counterparts. ${ }^{2}$ For example, in 2014, the purchasing-power-parity-adjusted GDP per capita of the EU-2 was about 42 percent and the life satisfaction was about 72 percent of that in the EU-15. ${ }^{3}$ Third, assessing the SWB impact of EU membership is important because numerous cross-sectional, longitudinal, and experimental studies demonstrate that happier people are more successful in multiple life domains (De Neve, Diener, Tay, \& Xuereb, 2013). The evidence shows that higher SWB levels are positively associated with outcomes such as better work performance, income, health, innovation, and social capital (Lyubomirsky, King, \& Diener, 2005). Furthermore, many of happy people's traits, such as optimism, social engagement, creativity, and good health, could also improve the lives of others and the quality of the social fabric. Given the challenges that Bulgaria and Romania face compared with the rest of the EU, if joining the EU is indeed linked to SWB, it could at least partially facilitate a smoother completion of the transition process-a winwin situation for both post-socialist countries and the rest of the EU.

We focus on Bulgaria and Romania because these countries are the EU's poorest and among the most unhappy and most corrupt member states (Helliwell, Huang, \& Wang,

\footnotetext{
2 The EU-15 countries are: Austria, Belgium, Denmark, Finland, France, Germany, Greece, Ireland, Italy, Luxembourg, Netherlands, Portugal, Spain, Sweden, and United Kingdom.

3 Authors' calculations based on data from the World Development Indicators and Gallup Analytics.
} 
2015; Transparency International, 2014). ${ }^{4}$ Moreover, unlike any other EU members, Bulgaria and Romania have post-membership monitoring through the Mechanism for Cooperation and Verification (MCV), which signals institutional deficiencies related to the fight of corruption and organized crime.

By focusing on life satisfaction as our outcome variable, we study the broad psychological well-being consequences of EU membership. SWB metrics, which comprise positive and negative feelings related to daily experiences, life satisfaction, and life purpose, reflect the idea that people are the best judges of their life circumstances (OECD, 2011) and provide "a natural way to aggregate various experiences in a way that reflects people's own preferences" (Stiglitz, Sen, \& Fitoussi, 2009, p. 145). ${ }^{5}$ Thus, by capturing both material and non-material aspects of life, SWB metrics can provide a more comprehensive understanding of the well-being consequences of complex processes such as joining the EU.

We use Eurobarometer data with information on individual life satisfaction and socio-demographic characteristics of respondents in Bulgaria and Romania, as well as those in Croatia, immediately before and after joining the EU on January 1, 2007. Specifically, EB data were collected in September-October, 2006 and then again in April-May, 2007, thus minimizing the influence of intervening events. ${ }^{6}$ Our identification strategy relies on a quasiexperiment, whose results could, at least theoretically, be interpreted as causal. Specifically, we use a difference-in-differences (DID) estimator, which takes into account general changes over time that are common to both treatment and counterfactual countries. This way we can difference out time-invariant omitted variables and macroeconomic shocks such as the great recession, provided that they affected the analyses countries similarly. In this setup, EU membership is the treatment, respondents Bulgaria and Romania are the treated group, and respondents in Croatia are the counterfactual group.

We find that joining the EU increased life satisfaction in Bulgaria. The estimated effect in Romania was positive but statistically insignificant at conventional levels. One possible reason for these results could be that trust towards the EU increased only in

\footnotetext{
${ }^{4}$ Along with Slovakia and Hungary, Bălţătescu (2007) considers Bulgaria and Romania among the least likely members to catch up with the EU-15 in terms of life satisfaction.

${ }^{5}$ In this paper, we use the terms subjective well-being (SWB) and life satisfaction synonymously. Happiness and life satisfaction are, however, two distinct dimensions of SWB with different determinants (Graham \& Nikolova, 2015; Stone \& Mackie, 2014).

${ }^{6}$ To the best of our knowledge, the Eurobarometer surveys are the only publicly available data allowing the reliable comparison of subjective well-being before and after the 2007 enlargement.
} 
Bulgaria after joining. In addition, Romania experienced political turmoil only a few months after EU membership, which may have negatively affected life satisfaction and canceled out the positive experiences related to joining the EU. A more detailed time breakdown of the effects shows positive life satisfaction increases even in Romania in the first two quarters of 2008 , after the political war subsided. In both countries, the positive life satisfaction effects of joining the EU were felt only after a lag, likely because Bulgarians and Romanians required time to start feeling European. Our evidence further suggests that the younger, employed, and those who ended their education between the ages of 16-19 benefited more from EU integration than their counterparts. The results are robust to placebo tests for two alternative "fake" EU entry years and to an estimation in which the standard error structure adjusts for the fact that we study the consequences of macro-level events on individual wellbeing. ${ }^{7}$

\section{Theoretical Considerations}

Delhey (2001) proposes a general model of how EU membership influences three welfare dimensions: material living conditions, quality of society, and subjective well-being. Specifically, instruments related to regional policy, institutional adjustments, and economic conditions directly improve material quality of life and social quality, which in turn indirectly affect SWB. We build on Delhey's (2001) work and propose four different channels through which EU integration can directly influence the SWB of Bulgarians and Romanians: (1) the adoption of shared economic and political institutions (modernization); (2) economic development; (3) freedom of choice and life control perception; and (4) social identity (Figure 1). Below we summarize the expected effect of each one of these four channels on SWB. Because each channel can have both positive and negative influences on SWB, we argue that the relationship between joining the EU and SWB is a priori ambiguous.

\subsection{Political and Economic Institutions (Modernization)}

The adoption of EU rules and standards was among the most anticipated benefits of EU integration in Bulgaria and Romania. To join the EU, each country had to fulfill the economic, political, and administrative criteria set during the Copenhagen European Council in 1993 - namely, democracy, rule of law, and human rights, protection of minorities

\footnotetext{
7 As explained below, to correct for Moulton bias, we use wild bootstrapped standard errors following Cameron et al. (2008).
} 
functioning market economy and the capacity to cope with competition and market forces; and the ability to adopt and implement the common body of law.

A growing literature in economics and political science demonstrates that people care not only about different socio-economic outcomes, but also about the processes that generate these outcomes (Frey, Benz, \& Stutzer, 2004; Frey and Stutzer, 2010). While the development of political and economic institutions consistent with free markets, democracy, and the rule of law started before 2007 and still continues today, EU membership provided Bulgarians and Romanians with a sense that they finally belong to a system in which outcomes are determined by just processes. In this sense, the shared political, legal, and economic institutions and the EU oversight provided people with a separate source of utility, i.e., procedural utility, which we expect to have positively influenced SWB as a result of the 2007 events.

While significant improvements in these areas were achieved with the EU's guidance prior to membership, these benefits came at the cost of implementing difficult reforms and adopting the numerous pages of the aquis communautaire (i.e., the EU common body of law). Joining the EU invariably also "cost" new members the adoption of norms and regulations, especially related to environmental protection, safety standards, and competition policy (whereby national governments could not aid national industries), which required difficult adjustments (O. Doyle \& Fidrmuc, 2006). For example, to comply with EU membership conditions, Bulgaria had to close two of its nuclear reactors that generated about a third of its electricity. Although both countries were recognized as having functioning democratic political systems by 2007, there were increasing concerns about corruption, lack of political leadership, and weak democratic institutions, which foreign media often exposed, and might have affected negatively the SWB of Bulgarians and Romanians.

\subsection{Economic Outcomes}

The adoption of a common legal and economic framework was expected to stabilize the economic environment, making it more attractive for local businesses and foreign investors. Thus, EU membership was largely anticipated to increase the share of foreign direct investment (FDI) creating more growth opportunities for Bulgarian and Romanian companies and ultimately leading to their faster integration into the global economy. In addition, the access to a huge new market, potential EU economic partners, development funds, and fresh capital was expected to boost economic development, lower 
unemployment, and raise the material standards of living of ordinary citizens, which numerous polls prior to membership revealed was perceived as the greatest benefit of EU membership. At the same time, there were fears that EU integration may lead to a rise in the costs of living, competitive pressures from foreign companies that could lead to local business bankruptcies, and a brain drain with educated people emigrating abroad.

While no data exist on the causal effect of joining the EU on the economic wellbeing in the EU-2, recent research suggests that the GDP per capita gains of joining the EU are relatively large and that EU-8 countries experienced similar gains to those in previous enlargements: about 13 percent (53 percent in Latvia) (Campos, Coricelli, \& Moretti, 2014). Furthermore, the convergence literature shows that EU membership has led to an economic catch-up in Ireland, Greece, Portugal and Spain as well as the CEE countries which joined in 2004 (Kaitila, 2004). Cavenaile and Dubois (2011) also find evidence for $\beta$-convergence (i.e., poorer EU members growing faster than the richer EU members) between the CEE members and the rest of the EU. Trade and FDI have been important drivers of convergence: the trade agreements between the EU-15 and the EU-10 (i.e., the Interim Agreements and the Europe Agreements) led to substantive contributions to GDP and welfare (Egger \& Larch, 2011). ${ }^{8}$ Welsch and Bonn (2008) show that macroeconomic convergence (and the convergence in inflation rates in particular) played a substantial role in the life satisfaction convergence in the EU in the 1990s. Given that short-run income increases are linked to SWB in transition and other economies (Easterlin, 2013), we expect that joining the EU positively influenced SWB in Bulgaria and Romania through economic development.

\subsection{Freedom of Choice and Life Control Perceptions}

Analyzing the SWB effect of the first two channels-modernization and economic development—is rather difficult because these processes started before EU membership and still continue today. For many Bulgarians and Romanians, however, the long anticipated EU membership meant that they could now travel, work ${ }^{9}$, study, invest, or retire abroad. These unprecedented freedoms opened doors to new opportunities for career development, self-

\footnotetext{
${ }^{8}$ Other papers examine convergence in living standards between old and new EU members (Cornelisse \& Goudswaard, 2002; Giannias, Liargovas, \& Manolas, 1999; Neumayer, 2003).

${ }^{9}$ Some EU15 countries such as Germany, Great Britain and France had provisional restrictions on immigration from the new member states up to 7 years, which expired in 2014. However, Bulgarians were able to work in 10 out of the 27 EU members including Sweden, Finland, and the Czech Republic, which significantly expanded their opportunity set.
} 
expression, and ultimately, for the pursuit of happiness. Indeed, a mid-2006 poll in Bulgaria indicated that over a third of respondents believed that the free movement of people and better job opportunities is the biggest benefit from joining the EU. ${ }^{10}$

A large literature in psychology shows that perceptions of freedom of choice and life control are a powerful motivator with implications for health, wealth, and happiness. People who believe that they have control over their lives, for example, are more likely to take action and persevere through hardship. They are more likely to save (Cobb-Clark, Kassenboehmer, \& Sinning, 2014), develop healthy habits (Cobb-Clark, Kassenboehmer, \& Schurer, 2014), escape drug addiction (Armitage, Armitage, Conner, Loach, \& Willetts, 1999), or invest more time searching for a job (Caliendo, Cobb-Clark, \& Uhlendorff, 2015). A number of recent studies have further suggested that the sense of control and freedom is one of the most robust SWB determinants (K. O. Doyle \& Youn, 2000; Inglehart, Foa, Peterson, \& Welzel, 2008; Verme, 2009).

In addition to being instrumentally important, freedom is also intrinsically valuable because it allows individuals to act in a deliberate and purposeful manner, exert power over their environment, and develop their talents by exercising autonomy and self-expression, two of the most basic human needs. Welzel (2013), for example, develops a theory of emancipation based on the human desire for a domination-free existence. He argues that free agency leads to the emergence of emancipative values, which in turn lead to a higher level of psychological well-being as people gain control over their society's agenda. In this respect, by expanding their opportunities, joining the EU may have provided EU-2 citizens with a greater sense of freedom of choice and life control, likely leading to higher SWB levels.

\subsection{Social Identity}

The final channel through which joining the EU may have affected SWB is what we refer to as "social identity." There are three possible mechanisms here. First, "the return to Europe" was not only symbolic for Bulgarians and Romanians, but also, and more importantly, made these countries a part of the largest economy in the world, that of the EU. As a result, people in the EU-2 might have experienced a sense of pride, accomplishment, and belonging, as they now formally belonged to an "elite" club of prosperous countries.

\footnotetext{
${ }^{10}$ Survey of 16-21 May 2006, conducted by ALPHA Research Agency, "Public Opinion for the Bulgarian membership to the EU, and the readiness of the country for a membership," published on 31.05.2006, available at: http://www.aresearch.org
} 
Second, even though Bulgarians and Romanians celebrated their return to Europe in 2007, they soon felt the bane of marginalization by being the poorest, and among the unhappiest and most corrupt EU members. Unprecedentedly, both countries became subject to ex-post-membership monitoring by the European Commission, which negatively affected their European identity. Corruption scandals froze many of the EU development funds in 2008 (Andreev, 2009; Spendzharova \& Vachudova, 2011). Major EU economic powers such as Great Britain, Germany, and France kept tight labor mobility restrictions for seven years that prevented Bulgarians and Romanian to freely work abroad. Furthermore, both countries suffered from an "image problem" as the Western media often portrayed them as sources of crime and prostitution.

Third, a growing body of literature suggests that the extent to which people feel satisfied with their lives depends, at least partially, on how they compare to those around them (Duesenberry, 1949; Frank, 1999; Scitovsky, 1976; Veblen, 1899). Joining the EU may have increased the material aspirations of people as they likely applied a higher benchmark for social comparisons. In this respect, even if European integration was marginally successful in economic and political terms, the negative image of "second-class" citizenry, the higher benchmark for social comparison, and the lower socio-economic status might have negatively affected SWB in the EU-2.

To summarize, joining the EU is a gradual process that involves multiple domains of political, economic, and social life. Separating the effect of economic development (such as pre- and post- accession funds, GDP growth, and investment) from the effect of modernization (changes in the structure of governance, adaptation to new rules and standards) in a before-after comparison based on a specific date is particularly difficult. However, the symbolic "return to Europe" on January 1, 2007 was highly anticipated in both countries. This event represented the beginning of a new era of opportunity, especially for the younger generations, that opened doors to Europe and significantly expanded the capabilities of ordinary citizens. Thus, we expect that, at least in the short run, EU membership had a positive effect on SWB through the channel of perception of freedom of choice and control. However, the lukewarm welcome of both countries to the EU, the mismanagement of EU funds that led to additional restrictions, and the image of "secondclass" Europeans might have completely offset the positive SWB effect from the EU integration in Bulgaria and Romania. 


\subsection{Previous Empirical Studies}

The literature on the well-being consequences of European integration is still in its infancy with only a few studies attempting to tackle issues of causality. ${ }^{11}$ In one exception, using DID, Popova (2012) finds that the Euro adoption led to life satisfaction declines for females, the elderly, the unemployed, and the poorest in the EU countries which joined the Eurozone in 2002. Yet, in new member states-Cyprus, Estonia, Malta, Slovenia, Slovakiabut not in Slovenia-the Euro adoption was positive or neutral for life satisfaction. In another paper, Wunder et al. (2008) find that the Euro adoption had a negative impact on satisfaction with income in Germany and the UK. Levitz and Pop-Eleches (2010) use a 2SLS strategy to examine the impact of the EU on the governance and democracy in the EU 2004 enlargement countries and conclude that there has been a modest post-membership reform slowdown but no backsliding. Finally, using a regression discontinuity design, Becker et al. (2010) find that the EU's structural funds have had a positive effect on GDP growth in the EU-25.

\section{Empirical Strategy}

\subsection{DID Overview and Choice of the Counterfactual}

Like Popova (2012) and Wunder et al. (2008), this paper uses difference-in-differences (DID) to study effect of EU integration on life satisfaction in Bulgaria and Romania. The DID method is commonly used to evaluate the consequences of various policies or treatments on certain outcomes. Our analysis compares the before-and-after SWB scores of individuals in Bulgaria and Romania (i.e. the treated group) to those of respondents in Croatia (i.e., the counterfactual or control group). During the study period of 2006-2008, Croatia was on a membership path but did not join the EU in 2007. The counterfactual demonstrates what would have happened to individual life satisfaction in the EU-2 if the two countries had not joined the EU. ${ }^{12}$

We argue that Croatia is an opportune counterfactual. First, historically, like Bulgaria and Romania, Croatia was a socialist republic, part of the former Socialist Republic of Yugoslavia, until the early 1990s. Unlike Bulgaria and Romania, Croatia experienced civil unrest between 1991-1995 but the 1990s and 2000s were marked by an economic, political,

11 Other papers such as Delhey (2001) and Bălţătescu (2007) study the life satisfaction convergence between old and new EU members using different EU enlargement waves.

12 The EB survey does not cover the transition countries in Central Asia and Albania, and polls for Serbia, Montenegro, and Macedonia are available only post-2007. EB first surveyed Croatia in 2004. 
and social transition similar to that in the EU-2. During the 2004-2013 period, Croatia experienced similar macroeconomic and institutional developments as the EU-2 (Figure 2). Second, the three countries are not only geographically close but also culturally alike. Importantly, the determinants of life satisfaction in the three countries are remarkably similar. According to the latest World Happiness Report, about three quarters of the variation in national average life evaluation scores are explained by six key variables: GDP per capita, social support, healthy life expectancy, freedom to make life choices, generosity, and control of corruption (Helliwell et al., 2015). Every country's national average score can be broken into parts explaining the relative contribution of each variable to the overall score. While the average scores in Bulgaria (4.2 on a scale of 0-10), Croatia (5.8), and Romania (5.1) are different, the patterns of factors that explain them are astonishingly similar. ${ }^{13}$ Finally, while Croatia joined the EU in 2013, it did not sign a Membership Treaty until December 9, 2011 and can therefore be used as a counterfactual country for the 2006-2008 time period.

Figure 3 demonstrates that Bulgaria and Romania have lower average (unadjusted) life satisfaction scores than Croatia. Yet, all three countries experienced similar life satisfactions trends prior to 2007, with a slight increase in SWB between the first and third quarters of 2006, and then a relatively stable trend until 2007.

\subsection{The DID Estimator}

In this context, the DID estimator is:

$$
\text { Lifesat }_{i t t}=\alpha+\beta E U 2_{c}+\gamma D_{t}+\lambda E U 2_{c} \times D_{t}+\mathrm{X}^{\prime}{ }_{\mathrm{ict}} \kappa+\varepsilon_{i c t}
$$

where $i$ indexes individuals, $c$ - countries, and $t$-years, LifeSat is the outcome variable (on a scale of 1 to 4); EU2 is a dummy equal to 1 if the observation comes from Bulgaria or Romania and 0 if it is from Croatia; and $D$ is a binary indicator for the period after EU membership (observations coming from 2007Q2 and after are coded as 1). The coefficient $\beta$ reflects the difference between life satisfaction levels between respondents in the treatment and the control countries and $\gamma$ demonstrates the time trends that would lead to a change in life satisfaction even in the absence of the treatment. The coefficient of interest is $\lambda$, which shows the average treatment effect on the treated (ATT), i.e., the effect of joining the EU on life satisfaction; $X$ is a vector of individual and household-level characteristics (age, age

${ }^{13}$ See Figure 2.2 in the World Happiness Report (Helliwell et al., 2015). 
squared, gender, education, employment, community size, household size, children in the household, etc.), $k$ is a coefficient vector, and $\varepsilon_{i t}$ is the stochastic error term. To account for anticipation and adaptation effects, as well as take advantage of the time-series data, we also use a model adapted from Acemoglu \& Angrist (2001):

$$
\text { Lifesatit }_{i t}=\alpha+\beta E U 2_{c}+\pi Q_{t}+\lambda E U 2_{c} \times Q_{t}+\mathrm{X}^{\prime} \mathrm{i}_{\mathrm{c} t \kappa}+\varepsilon i c t
$$

where the variables are defined as above, with $Q$ representing quarter of interview dummies (the reference category is the last quarter of 2005) and $\lambda E U 2^{c} \times Q_{t}$ is the full set of quarter - EU country interactions. Anticipation effects are captured by the $Q_{t} \times E U 2$ variables prior to 2007, and adaptation effects are shown in the post-2007 interactions. All analyses are for 2006-2008. We focus on a time span of two years for two reasons. First, by being broad well-being indicators, our SWB metrics help capture the complexities of the process of joining the EU and the responses of individuals to EU membership events but to other countrywide events as well. Our aim is to minimize the influence of the intervening events and to be able to isolate the effect of joining the EU as precisely as possible. Therefore, while using a longer time span may allow us to examine anticipation and adaptation effects, it will not allow us to control for intervening political and economic events. Second, the happiness literature finds that adaptation to various events usually happens within a few years. Therefore, our time span of three years is appropriate for our research purposes. ${ }^{14}$

Individual-level variables in the covariate vector increase precision (Angrist and Pischke 20009). The conditioning variables in $X$ must be independent of the treatment, i.e., respondents should not change their behavior and social characteristics in anticipation of EU membership (Lechner, 2011). The DID estimator also assumes that the treatment had no impact on the treated in the pre-treatment period (Lechner, 2011).

The DID estimator mitigates endogeneity related to time-invariant unobserved heterogeneity (Bertrand, Duflo, \& Mullainathan, 2004). Therefore, to the extent that unobservable differences between individuals that affect their well-being perceptions are constant over time, they cancel out in a DID model. The estimator's main assumption is that changes which occurred for reasons other than joining the EU affected the treatment and the control groups in the same way (i.e., the common trends assumption) (Abadie, 2005). This assumption implies that if Bulgaria and Romania had not joined the EU, they would

\footnotetext{
${ }^{14}$ In a similar setup studying the SWB effects of the Euro currency adoption, Popova (2012) uses three years of data, while Wunder et al. (2008) - two years - before and after the euro adoption.
} 
have experienced the same SWB trends as Croatia, conditional on the covariates (Lechner 2011). This assumption is difficult to verify but we show in Figure 3 that the EU-2 and Croatia followed similar life satisfaction trends in the period before 2007.

The DID methodology also assumes that no other major events significantly affected SWB during the membership period. While other events happened in the EU-2 countries in 2007, joining the EU was arguably the most significant national event for Bulgaria in that year (Eurofound, 2008). Romania, however, experienced a political war between the Presidency and the Government starting in early 2007, which may have negatively affected life satisfaction. In addition, the European Commission scolded Bulgaria in June and Romania in October 2007, which may have also lowered SWB in that quarter. The economic crisis, meanwhile, hit Bulgaria and Romania and Croatia with the same severity and roughly at the same time, which suggests that we can net out its influence on SWB with our DID strategy (Bartlett \& Monastiriotis, 2010). Moreover, while in western countries the economic crisis began in 2007, it was not until the last quarter of 2008 that it was felt in South Eastern Europe (Sanfrey, 2010), providing a further justification for our time span.

All models are estimated using OLS with robust standard errors. The choice of OLS is due to the problematic interpretation of the interaction term (i.e., the average treatment effect) in non-linear models with non-monotonic transformation functions (e.g., logits, probits, tobits) (Ai \& Norton, 2003). In addition, ignoring the ordinality of subjective wellbeing data has little effect on the results (Ferrer-i-Carbonell \& Frijters, 2004; Frijters \& Beatton, 2012).

\subsection{Limitations}

Our empirical strategy has several limitations. First, EU integration is a gradual process which involves multiple domains of social, economic, and political life. In this paper, we suggest several different channels- (1) modernization, (2) economic development, (3) perceptions of life control, and (4) social identity-through which EU integration may have affected how individuals perceive their quality of their life. While the advantage of SWB metrics is that they allow us to study multifaceted processes, which have both material and perceived dimensions, it is important to understand how EU integration affected SWB through each one of these channels. Yet, our strategy is designed to study the net effect rather the relative strength of each mechanism. 
Furthermore, while the DID results can in theory be interpreted as causal, readers should use caution. The DID strategy relies on the use of counterfactual countries-i.e., countries that are similar to Bulgaria and Romania, except that they did not become members in 2007. While Croatia, the counterfactual country in this study, has a similar economic, political, and social history to both Bulgaria and Romania, it also had its unique historical developments.

\section{Data and Summary Statistics}

\subsection{Subjective Well-being Metrics}

Our key outcome variable is life satisfaction, which is a reflective assessment of one's own life and complements objective well-being indicators by providing an overall assessment of individual preferences rather than an externally chosen well-being criterion (OECD, 2011). While scholars agree that SWB metrics are valid and reliable, psychometrically sound, and important complements to objective indicators such as gross domestic product (Diener, Inglehart, \& Tay, 2013; Krueger \& Schkade, 2008; OECD, 2013; Stiglitz, Sen, \& Fitoussi, 2009), two main challenges exist when using well-being scores for economic and policy analysis (OECD, 2011).

First, people may adapt to bad circumstances and learn to be happy amidst adversity or take pleasure in immoral behavior. As a result, SWB metrics should complement rather than substitute objective metrics. Second, SWB indicators may be non-comparable across individuals and may be affected by transient external factors (OECD 2011). The literature shows, however, that the latter concern is largely unjustified and that SWB metrics are comparable across individuals, countries, and time, and predict behavior reasonably well (Diener, Inglehart, \& Tay, 2013; Diener, Suh, Lucas, \& Smith, 1999; Helliwell, BarringtonLeigh, Harris, \& Huang, 2010; Krueger \& Schkade, 2008). Scholars have used the life satisfaction approach to study the well-being effects of various macroeconomic policies and phenomena such as inflation and unemployment (DiTella, MacCulloch, \& Oswald, 2001), the welfare effects of EU integration (Wunder et al., 2008), and the impact of the recent financial crisis (Graham, Chattopadhyay, \& Picon, 2010).

\subsection{Eurobarometer Data}

Our data are from the Eurobarometer (EB) surveys which, to our knowledge, is the only publicly available dataset allowing the reliable comparison of SWB immediately before and after the 2007 enlargement. EB surveys are collected at least twice a year, thus providing 
observations immediately before and after joining the EU. ${ }^{15}$ In the case of Bulgaria and Romania, which joined on January 1, 2007, EB data were collected in September-October, 2006 (Q3 of 2006) and then again in April-May, 2007 (Q2 of 2007), thus minimizing the influence on life satisfaction of intervening events other than joining the EU.

Starting with EB 62 (October-November, 2004) Bulgaria, Romania, and Croatia are polled as part of the Standard Eurobarometer. The dataset has consistent information about gender, age, years at which education was stopped, employment status, household size, marital status, and household location. There are, however, no consistent income or expenditure variables but we instead construct a wealth index, which sums the ownership of household durables. The EB life satisfaction question asks respondents how satisfied they are on the whole with their life on a scale from 1 "not at all satisfied" to 4 "very satisfied" with no "neutral" category.

\subsection{Summary Statistics}

Table 1 collapses the data into two periods: before and after 2007. Life satisfaction in Bulgaria rose by 0.127 points post-membership (on a scale from 1 to 4). In Romania, it rose by 0.092 points, while it remained virtually unchanged in Croatia (a change of 0.007 ). The change in life satisfaction in Bulgaria and Romania is statistically significant while the change in Croatia is not. The rest of Table 1 summarizes the main socio-demographic variables included in the regressions.

\section{Empirical Findings}

\subsection{Main Results}

Table 2 shows our baseline estimates regarding the effects of joining the EU on the life satisfaction of Bulgarians and Romanians. ${ }^{16}$ We estimated three different models for each EU-2 country-Bulgaria (left panel) and Romania (right panel). Models (1) and (4) present our most basic specification without any controls while Model (2) and (5) add individuallevel socio-demographic variables. ${ }^{17}$ Finally, in addition to individual controls and quarter of

\footnotetext{
15 The following EB surveys are included in the main analysis and in the robustness checks: 63.1, 63.4, 64.2, $65.2,66.1,67.2,68.1,69.2,70.1,71.1,71.2,71.3$. In the main analyses (2006-2008), we include only 65.2, 66.1, $67.2,68.1,69.2,70.1$. While there are two other EB surveys in $2009-72.1$ and 72.4 -we did not include them as EB 72.1 does not poll Croatia and 72.4 did not have the exact date of the interview.

16 The treatment variable (EU-2×2007Q2) is the interaction term between the EU-2 variable (i.e., a dummy for either Bulgaria or Romania) with a dummy for the post-membership period (2007Q2 and after).

${ }^{17}$ We include age and its squared term, gender, an indicator for whether the respondent is married or in a civil partnership, a married $\times$ gender interaction, employment status, household size and its squared term, an
} 
interview dummies, Models (3) and (6) include a wealth index, which we compute by adding the total number of household durables such as cars, TVs, computers, and others. Models (3) and (6) are thus the most conservative.

The SWB effects associated with joining the EU are reflected in the coefficient estimate of the interaction term EU-2×2007Q2.$^{18}$ Models (1)-(3) suggest that joining the EU was associated with increase in life satisfaction in Bulgaria in the range of 0.076 (Model 3) to 0.120 (Model 1). In other words, Bulgarians' life satisfaction increased by about 0.1 points due to joining the EU. Given that life satisfaction is measured on a scale of 1-4, an increase of 0.1 is a small but economically meaningful effect. Results from EB 79.3 (May, 2013) show that life satisfaction was 2.05 in Bulgaria and 2.31 in Romania compared with 3.66 in Denmark (the happiest EU member), with an EU-15 average of 3.00. In this context, the life satisfaction change that we report in Bulgaria, constitutes about 14 percent of the 2013 life satisfaction gap between Bulgaria and the EU-15.

In Romania, the evidence on the life satisfaction consequences of joining the $\mathrm{EU}$ is less conclusive. Model (4) suggests that there was a 0.09 increase in life satisfaction but the result does not hold once we add socio-demographic characteristics and quarter of interview dummies in Models (5)-(6). Therefore, we conclude that there was no statistically significant change in life satisfaction in Romania due to the joining of the EU. One possible explanation, explored below, is that Bulgarians and Romanians had different attitudes towards the EU. Another possibility is that the positive well-being effects of joining the EU were offset by the political war that took place in Romania shortly after EU accession (Andreev, 2009). Starting with the withdrawal of the President Basescu's Democratic Party from the coalition government of Prime Minister Tariceanu, a back-and-forth between the President and the Tariceanu paralyzed the country's political life and spreading anxiety in Romanian society.

indicator for whether there are any children in the household, an indicator for a large or small town, and ageeducation categories.

${ }^{18}$ In all models, the EU dummy is negative and statistically significant reiterating the fact that individuals in Bulgaria and Romania have lower baseline life satisfaction than their Croatian counterparts. In particular, depending on the model, life satisfaction in Bulgaria is between 0.58 to 0.75 points lower compared to Croatia, while the (conditional) life satisfaction difference between Romanians and Croatians is between 0.32 and 0.47 points lower in Romania (on a scale of 1 to 4 ). 


\subsection{Anticipation and Adaptation Effects}

Table 3 delves deeper into the exact timing of the life satisfaction effects of joining the EU in Romania and Bulgaria. The coefficient estimates of interest are the quarter EU2 interactions (2005Q4 is the base period.) These interactions describe the EU-related change in life satisfaction in Bulgaria and Romania (relative to 2005 Q4). The pre-2007 interactions capture anticipation effects, which in theory should be zero since we expect increase in life satisfaction only after the membership. The post-2008 interactions reflect adaptation effects.

As expected, the results imply limited anticipation effects in 2006 in both countries. ${ }^{19,20}$ Joining the EU had no immediate well-being effects on life satisfaction in the first three quarters of 2007 in both countries. A positive and statistically significant effect from joining the EU in Bulgaria was observed starting with the fourth quarter of 2007 and thereafter. Our estimates for Bulgaria suggest that life satisfaction increased by about 0.2 on a scale of 1 to 4 in the last quarter of 2007. In Romania, there was an EU-membershiprelated increase in life satisfaction in the first two quarters of 2008, after the end of the political strife of 2007, but the effect disappears afterwards. The fact that EU membership increased life satisfaction in the EU-2 only after a lag could be due to the negative effects coming from the social identity channel described in Section 2.4 and the lukewarm welcome of both countries to the EU, in particular. Even though Bulgaria and Romania became EU members in 2007, the foreign media and the EU Commission scolded them for not making progress on reducing corruption and organized crime. Building an EU identity was likely a gradual process requiring citizens in both countries to learn "the rules of the game" and to take advantage of the freedoms and opportunities related to their EU membership. As explained above, the lack of positive effects in Romania before 2008 could also be due to the concurrent political war in 2007, which likely mired the positive well-being effects of EU membership.

\subsection{Results by Socio-Demographic Groups}

While the EU symbolizes political and economic stability for both elites and ordinary citizens, the process invariably had winners and losers (Tucker, Pacek, \& Berinsky, 2002). Specifically, those who gained the most from the transition process-the educated, the

${ }^{19}$ As in Table 2, the coefficient for the EU-2 indicator in Table 3 shows that life satisfaction in both Romania and Bulgaria was about 0.47 and 0.79 points lower than that in Croatia, respectively.

${ }^{20}$ In Bulgaria, we find a positive but marginally statistically significant change in life satisfaction in the last quarter of 2006 , just prior to membership. 
upwardly mobile, and the young-likely also benefited the most from EU membership and the enhanced opportunities that came with it. The literature suggests that the elderly, the less educated, and women were among the losers of transition (Easterlin, 2009). How these groups experienced transition likely also affected their perceptions of EU membership and life satisfaction (Tucker et al., 2002). To explore the possibility that the effects differ by socio-demographic status, Tables 4-6 examine the SWB effects of joining the EU by age group, employment status, and education, respectively.

Overall, our results indicate that younger cohorts benefited more from EU membership than older ones, but only in the case of Bulgaria (Table 4). The ATT, although positive, is statistically insignificant for all age groups in Romania. Specifically, our results imply that as a result of joining the EU, the life satisfaction for Bulgarians under 35 years of age increased by 0.152 points. For those aged 36-60 at the time of the interview, life satisfaction rose by 0.122 points on average, but there were no statistically significant effects for people above the age of 60 . These results are unsurprising since many of the benefits of joining the EU such as opportunities to travel, work, and study abroad primarily increased the choice set of the young.

Table 5 summarizes the results by employment and retirement status at the time of the interview. The results in are consistent with previous findings in the literature suggesting that the winners of EU integration were primarily the employed. Interestingly, Panel A, suggests that even in Romania, employed respondents experienced SWB gains relative to those who were not working at the time of the interview (comparing Models (3) and (4)). Meanwhile, the unemployed in Bulgaria and Romania experienced no change in life satisfaction due to joining the EU.

Finally, in Table 6 we explore the results according to the age at which the respondents stopped their full-time education. The results show that even the most educated Bulgarians and Romanians have a much lower baseline life satisfaction compared to their counterparts in Croatia (as shown by the coefficient estimate for the EU-2 Country indicator in the top row). Our findings indicate that only respondents who stopped their education when they were 16-19 years old experienced positive SWB gains in both countries, while the estimated coefficients for the least and most educated groups are statistically insignificant in both countries. 
We find no gender differences in either Bulgaria or Romania (Appendix Table A1). Although Easterlin (2009) suggests that women may have been the losers of transition, our results are in line with the Life in Transition Survey II, which finds no significant differences between men and women in transitional economies in terms of life satisfaction, job satisfaction, and how they have done relative to others (EBRD, 2010).

\subsection{The Effects of Joining the EU on Bulgarians' and Romanians' EU Trust}

So far, our results suggest that joining the EU increased life satisfaction in Bulgaria while the outcomes for Romania, although positive in most regressions, are statistically insignificant. There are many possible reasons for these results as we discuss in section 2 . To aggregate the variety of unobserved experiences that may have led to different perception of the EU integration process in Bulgaria and Romania, we examine how people's trust towards the EU changed after the membership in 2007. Table 7 summarizes our findings, which replicate our baseline models from Table 2, but using trust towards the EU as the dependent variable. The results suggest that while EU trust increased post-accession in Bulgaria, it remained virtually unchanged in Romania. This could be one possible reason why life satisfaction increased in Bulgaria, but remained flat in Romania, especially given the literature linking EU trust to increases in life satisfaction in the EU countries (Hudson, 2006).

\subsection{Robustness Checks}

First, we replicate our main results using two alternative fake entry dates to the EU, namely, the last quarter of 2005 and the first quarter of 2009. The interaction term between the fake entry date and the EU dummy should be statistically insignificant as no EU-related events happened in these two quarters. The results are summarized in Table 8. As expected, we find no significant effects for Bulgaria when we use a fake treatment year. In the case of Romania, we find some negative effects when we use 2005 as fake entry year, but these effects disappear in our most conservative model (Model (6)). This suggests that our results are robust: we see positive SWB changes in Bulgaria only in 2007, the true year of membership.

Second, we replicate our results using wild bootstrapped standard errors, clustered at the country $\times$ quarter level (Cameron et al., 2008). Measuring the effects of policy variables individual outcomes leads to interdependent residuals with a group structure (Moulton, 1990). Yet, a simple correction using clustered standard errors may bias the results when there are too few clusters, which is why we use the bootstrapped errors proposed by 
Cameron et al. (2008). The results (Table 9) are consistent with our main findings. Furthermore, even the effects for Romania are now positive and statistically significant. It is important to note, however, that since we have only two countries and nine quarters, these results should be treated with caution.

\section{Conclusion}

The fall of the socialist regimes in Central and Eastern Europe marked the beginning of a long transition process that promised a European future and socio-economic, political, and institutional change. While the EU has been remarkably successful in promptly facilitating and shaping the reform efforts of other CEE countries, Bulgaria and Romania's democratization and marketization reforms have been slow and painful, leading to a delayed accession process. Yet, the membership aspirations and EU enlargement policy have helped the two countries escape the post-socialist stalemate and ultimately broadly fulfill the Copenhagen criteria and join the Union in 2007 (Noutcheva \& Bechev, 2008).

How did the event of "returning to Europe" affect the lives of ordinary Bulgarians and Romanians? This is the first study to examine the effect of joining the EU on life satisfaction in the context of the $2007 \mathrm{EU}$ enlargement, i.e., the membership of Bulgaria and Romania. Using a difference-in-differences strategy and Eurobarometer data, our key finding is that EU membership increased average life satisfaction in Bulgaria, and had a positive, but statistically insignificant effect in Romania. One possible explanation for this finding is that trust towards the EU increased in Bulgaria after joining, but remained unchanged in Romania where the political war of 2007 likely mired the more positive EU-related experiences in that year.

Our heterogeneity analyses show that those who benefited the most from EU integration were the young, the employed, and those who ended their education between the ages of 16-19, while we discovered no gender differences. A more disaggregated analysis revealed that life satisfaction boosts in Bulgaria started in the last quarter of 2007 and that there were some positive EU-related life satisfaction increases in Romania in the first two quarters of 2008. In short, in both countries, EU membership translated into life satisfaction benefits only after a lag. These results suggest that both Bulgarians and Romanians required time to learn to be European and to be satisfied with their EU membership, and the benefits and challenges it brought. 
From a policy perspective, these findings are relevant to the countries in the Western Balkans which are in various stages of their EU integration processes. Like Bulgaria and Romania, these candidate countries are less advanced and less prepared for membership than the 2004 enlargement countries. As the EU's poorest and unhappiest members, Bulgaria and Romania also face challenges in terms of closing the quality of life gap with the EU-15. While the EU has helped its newest members with macroeconomic convergence, this paper demonstrates that joining the EU was also associated with life satisfaction gains, at least in the case of Bulgaria. Whether these developments will help the EU-2 to close the gap remains to be seen.

It is important to note, however, that Bulgaria and Romania continue to be rank among the EU's least happy members, with Bulgaria being at the bottom (Helliwell et al., 2015). The latest World Happiness Report shows that with a happiness score of 4.2 on a scale of 0 to 10, Bulgaria ranked 134th among 158 countries (Helliwell et al., 2015). Romania's score of 5.1 put it on position 86 out of 158 countries, compared with a score of 7.5 in Denmark, the EU's happiest and the world's third happiest nation. Our analyses for 2014 using Gallup Analytics show an average life satisfaction (best possible life) score of 4.9 for Bulgaria and Romania, compared to an EU-15 average of 6.8. Thus, the EU-related life satisfaction boost that our study finds for Bulgarians and, to some extent, Romanians, appears to be a short-run phenomenon, perhaps largely based on the transient hopes of ordinary citizens that joining the EU will speed up the transition to a modern democracy governed by the rule of law. While a pivotal historical event, joining the EU on its own is not a silver bullet and cannot close the quality of life gap between the EU-2 and the EU-15. Becoming a EU citizen in the legal sense can happen over night, but learning to be European is a complex process, which entails both positive and negative experiences with a period of adjustment and adaptation. While our study shows that EU membership could raise the life satisfaction of new members in the short run, joining the EU is by no means a substitute for social transformation and national reforms targeted at improving the governance and quality of life in transition countries. 


\section{References}

Abadie, A. (2005). Semiparametric Difference-in-Differences Estimators. The Review of Economic Studies, 72(1), 1-19.

Acemoglu, D., \& Angrist, J. D. (2001). Consequences of Employment Protection? The Case of the Americans with Disabilities Act. Journal of Political Economy, 109(5), 915-957.

Ai, C., \& Norton, E. C. (2003). Interaction Terms in Logit and Probit Models. Economics Letters, 80(1), 123-129.

Andreev, S. A. (2009). The Unbearable Lightness of Membership: Bulgaria and Romania After the 2007 EU Accession. Communist and Post-Communist Studies, 42(3), 375-393.

Armitage, C. J., Armitage, C. J., Conner, M., Loach, J., \& Willetts, D. (1999). Different Perceptions of Control: Applying an Extended Theory of Planned Behavior to Legal and Illegal Drug Use. Basic and Applied Social Psychology, 21(4), 301-316.

Åslund, A. (2007). How Capitalism W as Built: The Transformation of Central and Eastern Europe, Russia, and Central Asia. New York, NY: Cambridge University Press.

Bălţătescu, S. (2007). Life Satisfaction of the New EU Members: Recent Trends and Future Prospects. Working Paper. Available at: http://www.lu.lv/jmconference2006/dokumenti/Papers/Sergiu_Baltatescu.pdf

Bartlett, W., \& Monastiriotis, V. (Eds.). (2010). South East Europe after the Economic Crisis: A New Dawn or Back to Business as Usual. London, UK: London School of Economics Reprographics Department.

Becker, S. O., Egger, P. H., \& von Ehrlich, M. (2010). Going NUTS: The Effect of EU Structural Funds on Regional Performance. Journal of Public Economics, 94(9/10), 578-590.

Bertrand, M., Duflo, E., \& Mullainathan, S. (2004). How Much Should We Trust Differences-inDifferences Estimates? The Quarterly Journal of Economics, 119(1), 249-275.

Caliendo, M., Cobb-Clark, D. A., \& Uhlendorff, A. (2015). Locus of Control and Job Search Strategies. Review of Economics and Statistics, 97(1), 88-103.

Cameron, A. C., Gelbach, J. B., \& Miller, D. L. (2008). Bootstrap-based Improvements for Inference with Clustered Errors. Review of Economics and Statistics, 90(3), 414-427.

Campos, N. F., Coricelli, F., \& Moretti, L. (2014). Economic Growth and Political Integration: Estimating the Benefits from Membership in the European Union Using the Synthetic Counterfactuals Method. IZA DP No. 8162, 1-37.

Cavenaile, L., \& Dubois, D. (2011). An Empirical Analysis of Income Convergence in the European Union. Applied Economics Letters, 18(17), 1705-1708.

Cobb-Clark, D. A., Kassenboehmer, S. C., \& Schurer, S. (2014). Healthy Habits: The Connection between Diet, Exercise, and Locus of Control. Journal of Economic Behavior \& Organization, 98, $1-28$.

Cobb-Clark, D. A., Kassenboehmer, S. C., \& Sinning, M. G. (2014). Locus of Control and Savings. IZA DP No. 7837, 1-45.

Cornelisse, P. A., \& Goudswaard, K. P. (2002). On the Convergence of Social Protection Systems in the European Union. International Social Security Review, 55(3), 3-17.

European Commission. (2012). Eurobarometer 71.3 (Jun-Jul 2009). TNS OPINION \& SOCIAL, Brussels [Producer]. GESIS Data Archive, Cologne. ZA4973 Data file Version 3.0.0, doi:10.4232/1.11135

European Commission. (2012). Eurobarometer 71.2 (May-Jun 2009). TNS OPINION \& SOCIAL, Brussels [Producer]. GESIS Data Archive, Cologne. ZA4972 Data file Version 3.0.2, doi:10.4232/1.10990

European Commission. (2012). Eurobarometer 70.1 (Oct-Nov 2008). TNS OPINION \& SOCIAL, Brussels [Producer]. GESIS Data Archive, Cologne. ZA4819 Data file Version 3.0.2, $\underline{\text { doi: } 10.4232 / 1.10989}$ 
European Commission. (2012). Eurobarometer 68.1 (Sep-Nov 2007). TNS OPINION \& SOCIAL, Brussels [Producer]. GESIS Data Archive, Cologne. ZA4565 Data file Version 4.0.1, doi:10.4232/1.10988

European Commission. (2012). Eurobarometer 67.2 (Apr-May 2007). TNS OPINION \& SOCIAL, Brussels [Producer]. GESIS Data Archive, Cologne. ZA4530 Data file Version 2.1.0, doi:10.4232/1.10984

European Commission. (2012). Eurobarometer 66.1 (Sep-Oct 2006). TNS OPINION \& SOCIAL, Brussels [Producer]. GESIS Data Archive, Cologne. ZA4526 Data file Version 1.0.1, doi:10.4232/1.10980

European Commission. (2012). Eurobarometer 65.2 (Mar-May 2006). TNS OPINION \& SOCIAL, Brussels [Producer]. GESIS Data Archive, Cologne. ZA4506 Data file Version 1.0.1, doi:10.4232/1.10974

European Commission. (2012). Eurobarometer 64.2 (Oct-Nov 2005). TNS OPINION \& SOCIAL, Brussels [Producer]. GESIS Data Archive, Cologne. ZA4414 Data file Version 1.1.0, doi:10.4232/1.10970

European Commission (2012): Eurobarometer 63.4 (May-Jun 2005). TNS OPINION \& SOCIAL, Brussels [Producer]. GESIS Data Archive, Cologne. ZA4411 Data file Version 1.1.0, doi:10.4232/1.10968

European Commission (2012): Eurobarometer 63.1 (Jan-Feb 2005). TNS OPINION \& SOCIAL, Brussels [Producer]. GESIS Data Archive, Cologne. ZA4233 Data file Version 1.1.0, doi:10.4232/1.10965

European Commission. (2013). Eurobarometer 71.1 (Jan-Feb 2009). TNS OPINION \& SOCIAL, Brussels [Producer]. GESIS Data Archive, Cologne. ZA4971 Data file Version 4.0.0, doi:10.4232/1.11756

European Commission. (2013). Eurobarometer 69.2 (Mar-May 2008). TNS OPINION \& SOCIAL, Brussels [Producer]. GESIS Data Archive, Cologne. ZA4744 Data file Version 5.0.0, doi:10.4232/1.11755

De Neve, J.-E., Diener, E., Tay, L., \& Xuereb, C. (2013). The Objective Benefits of Subjective Wellbeing. In J. F. Helliwell, R. Layard, \& J. Sachs (Eds.), World Happiness Report (pp. 54-79).

Delhey, J. (2001). The Prospects of Catching up for New EU Members: Lessons for the Accession Countries to the European Union from Previous Enlargements. Social Indicators Research, 56(2), 205-231.

Diener, E., Inglehart, R., \& Tay, L. (2013). Theory and validity of life satisfaction scales. Social Indicators Research, 112(3), 497-527.

Diener, E., Suh, E. M., Lucas, R. E., \& Smith, H. L. (1999). Subjective Well-being: Three Decades of Progress. Psychological Bulletin, 125(2), 276-302.

DiTella, R., MacCulloch, R. J., \& Oswald, A. (2001). Preferences over Inflation and Unemployment: Evidence from Surveys of Happiness. The American Economic Review, 91(1), 335-341.

Doyle, K. O., \& Youn, S. (2000). Exploring the Traits of Happy People. Social Indicators Research, 52(2), 195-209.

Doyle, O., \& Fidrmuc, J. (2006). Who favors enlargement?: Determinants of Support for EU Membership in the Candidate Countries' Referenda. European Journal of Political Economy, 22(2), 520-543.

Duesenberry, J. S. (1949). Income, Saving, and the Theory of Consumer Behavior. Cambridge, MA: Harvard University Press.

Easterlin, R. (2013). Happiness and Economic Growth: The Evidence. IZA DP No. 7187. 1-30.

EBRD. (2010). Chapter 5: Gender Differences in Social Integration. Life In Transition: After The Crisis. Available at: http://www.ebrd.com/downloads/research/surveys/LiTS2ee.pdf

Egger, P., \& Larch, M. (2011). An Assessment of the Europe Agreements' Effects on Bilateral Trade, GDP, and Welfare. European Economic Review, 55(2), 263-279.

EU. (2007, 13 December). European Union. Treaty of Lisbon Amending the Treaty on European Union and the Treaty Establishing the European Community 2007/C 306/01. 
Ferrer-i-Carbonell, A., \& Frijters, P. (2004). How Important is Methodology for the Estimates of the Eeterminants of Happiness?. The Economic Journal, 114(497), 641-659.

Frank, R. H. (1999). Luxury Fever: Money And Happiness In An Era Of Excess. Princeton, NJ: Princeton University Press.

Frijters, P., \& Beatton, T. (2012). The Mystery of the U-shaped Relationship between Happiness and Age. Journal of Economic Behavior \& Organization, 82(2), 525-542.

Giannias, D., Liargovas, P., \& Manolas, G. (1999). Quality of Life Indices for Analysing Convergence in the European Union. Regional Studies, 33(1), 27-35.

Graham, C., Chattopadhyay, S., \& Picon, M. (2010). Adapting to Adversity: Happiness and the 2009 Economic Crisis in the United States. Social Research: An International Quarterly, 77(2), 715-748.

Graham, Carol, \& Nikolova, Milena. (2015). Bentham or Aristotle in the Development Process? An Empirical Investigation of Capabilities and Subjective Well-Being. World Development, 68, 163179.

Helliwell, J. F., Barrington-Leigh, C. P., Harris, A., \& Huang, H. (2010). International Evidence on the Social Context of Well-being. In E. Diener, J. F. Helliwell, \& D. Kahneman (Eds.), International Differences in Well-Being. New York: Oxford University Press.

Helliwell, J. F., Huang, H., \& Wang, S. (2015). The Geography of World Happiness. In J. F. Helliwell, R. Layard, \& J. Sachs (Eds.), World Happienss Report 2015 (pp. 12-41). New York.

Hudson, J. (2006). Institutional Trust and Subjective Well-Being across the EU. Kyklos, 59(1), 43-62.

Inglehart, R., Foa, R., Peterson, C., \& Welzel, C. (2008). Development, Freedom, and Rising Happiness: A Global Perspective (1981-2007). Perspectives on Psychological Science, 3(4), 264-285.

Kaitila, V. (2004). Convergence of Real GDP Per Capita in the EU15. How do the Accession Countries Fit in? European Network of Economic Policy Research Institutes Working Paper No. 25. Available at: http://aei.pitt.edu/1843/1/ENEPRI_WP25.pdf.

Krueger, A. B., \& Schkade, D. A. (2008). The Reliability of Subjective Well-being Measures. Journal of Public Economics, 92(8/9), 1833-1845.

Lechner, M. (2011). The Estimation of Causal Effects by Difference-in-Difference Methods. St. Gallen, Switzerland: Department of Economics, University of St. Gallen.

Levitz, Philip, \& Pop-Eleches, Grigore. (2010). Why No Backsliding? The European Union's Impact on Democracy and Governance before and after Accession. Comparative Political Studies, 43(4), 457-485.

Lyubomirsky, S., King, L., \& Diener, E. (2005). The Benefits of Frequent Positive Affect: Does Happiness Lead to Success? Psychological Bulletin, 131(6), 803.

Moulton, B. R. (1990). An Illustration of a Pitfall in Estimating the Effects of Aggregate Variables on Micro Units. The review of Economics and Statistics, 72(2), 334-338.

Neumayer, E. (2003). Beyond Income: Convergence in Living Standards, Big Time. Structural Change and Economic Dynamics, 14(3), 275-296.

Noutcheva, Gergana, \& Bechev, Dimitar. (2008). The Successful Laggards: Bulgaria and Romania's Accession to the EU. East European Politics \& Societies, 22(1), 114-144.

OECD. (2011). How's Life?: Measuring well-being: Organisation for Economic Cooperation and Development, OECD Publishing, Available at: http://dx.doi.org/10.1787/9789264121164en.

OECD. (2013). OECD Guidelines on Measuring Subjective Well-being: Organisation for Economic Cooperation and Development, OECD Publishing. Available at: http://www.oecd.org/statistics/Guidelines $\% 20$ on $\% 20$ Measuring $\% 20$ Subjective $\% 20$ Wellbeing.pdf.

Popova, O. (2012). Essays on Individual Perceptions of Economic Reforms. Ph.D. Dissertation. Center for Economic Research and Graduate Education (CERGE). Charles University Prague.

Sanfrey, P. (2010). South-eastern Europe: lessons from the global economic crisis EBRD Working Paper No. 113. London, UK: European Bank for Reconstruction and Development.

Scitovsky, T. (1976). The Joyless Economy: An Inquiry into Human Satisfaction and Consumer Dissatisfaction. Oxford, UK: Oxford University Press. 
Spendzharova, A. B., \& Vachudova, M. A. (2011). Catching Up? Consolidating Liberal Democracy in Bulgaria and Romania after EU Accession. West European Politics, 35(1), 39-58.

Stiglitz, J., Sen, A., \& Fitoussi, J.-P. (2009). The Measurement of Economic Performance and Social Progress Revisited. Reflections and Overview. Commission on the Measurement of Economic Performance and Social Progress, Paris. Available at: http://www.ofce.sciences-po.fr/pdf/dtravail/WP200933.pdf

Stone, A. A., \& Mackie, C. (2014). Subjective Well-Being: Measuring Happiness, Suffering, and Other Dimensions of Experience: Washington, DC: National Academies Press.

Transparency International. (2014). Visualising the Corruption Perceptions Index 2014: European Union and Western Europe. Available at:

http://www.transparency.org/cpi2014/infographic/regional/european-union-and-westerneurope

Tucker, J. A., Pacek, A. C., \& Berinsky, A. J. (2002). Transitional Winners and Losers: Attitudes toward EU Membership in Post-communist Countries. American Journal of Political Science, 557-571.

Veblen, T. (1899). The Leisure Class: French Translation (1970): La théorie de la classe de loisir, Gallimard, Paris.

Verme, P. (2009). Happiness, Freedom and Control. Journal of Economic Behavior \& Organization, 71(2), 146-161.

Welsch, H., \& Bonn, U. (2008). Economic Convergence and Life Satisfaction in the European Union. The Journal of Socio-Economics, 37(3), 1153-1167.

Welzel, C. (2013). Freedom rising. Cambridge, UK: Cambridge University Press.

Wunder, C., Schwarze, J., Krug, G., \& Herzog, B. (2008). Welfare Effects of the Euro Cash Changeover. European Journal of Political Economy, 24(3), 571 - 586. 


\section{Tables and Figures}

Figure 1: Channels Through Which EU Membership Affects SWB

\section{Modernization}

CHANGES IN THE STRUCTURE OF GOVERNANCE, ADAPTATION TO NEW RULES AND STANDARDS, SHARED POLITICAL AND BCONOMIC INSTTTUTIONS, PROCEDURAL UTHUTY

\section{EConomic OUTCOMEs}

ECONOMIC GROWTH, FOREIGN DIRECT INVESTMENT, UNEMPLOYMENT, INFLATION, SUBSIDIES, INTEGRATION INTO THE GLOBAL ECONOMY

JoINING

\section{Perception of Freedom of Choice}

WELL-BEING

OPPORTUNITIES TO TRAVEL, INVEST, WORK, STUDY, OR RETIRE ABROAD, EMANCIPATIVE VALUES, AUTONOMY AND SEFL-EXPRESSION

\section{Social IdentrTy}

THE RETURN TO EUROPE (SENSE OF PRIDE AND BELONGING), PERCEPTION OF SECOND CLASS CITIZENRY, SOCIAL COMPARISONS

Source: Authors 
Figure 2: Real GDP Per Capita, Inflation, Unemployment, and Rule of Law Trends in Bulgaria, Romania, and Croatia, 2004-2013
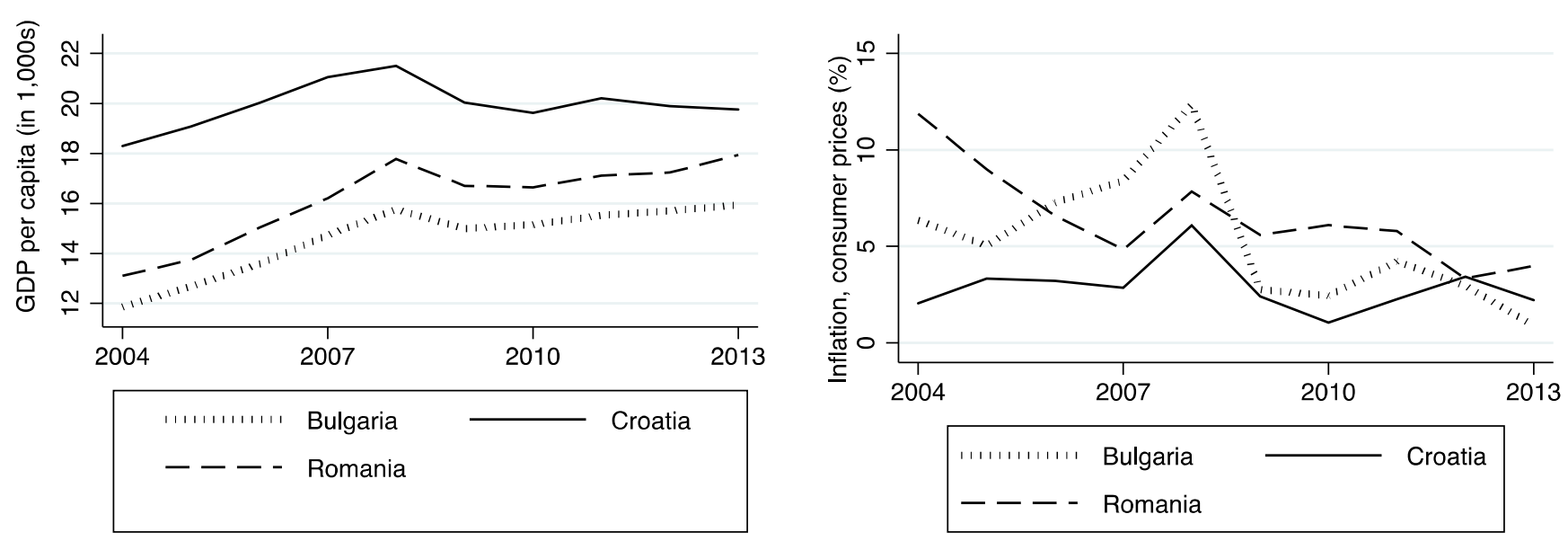

Note: in 1,000s of PPP constant 2011 international \$
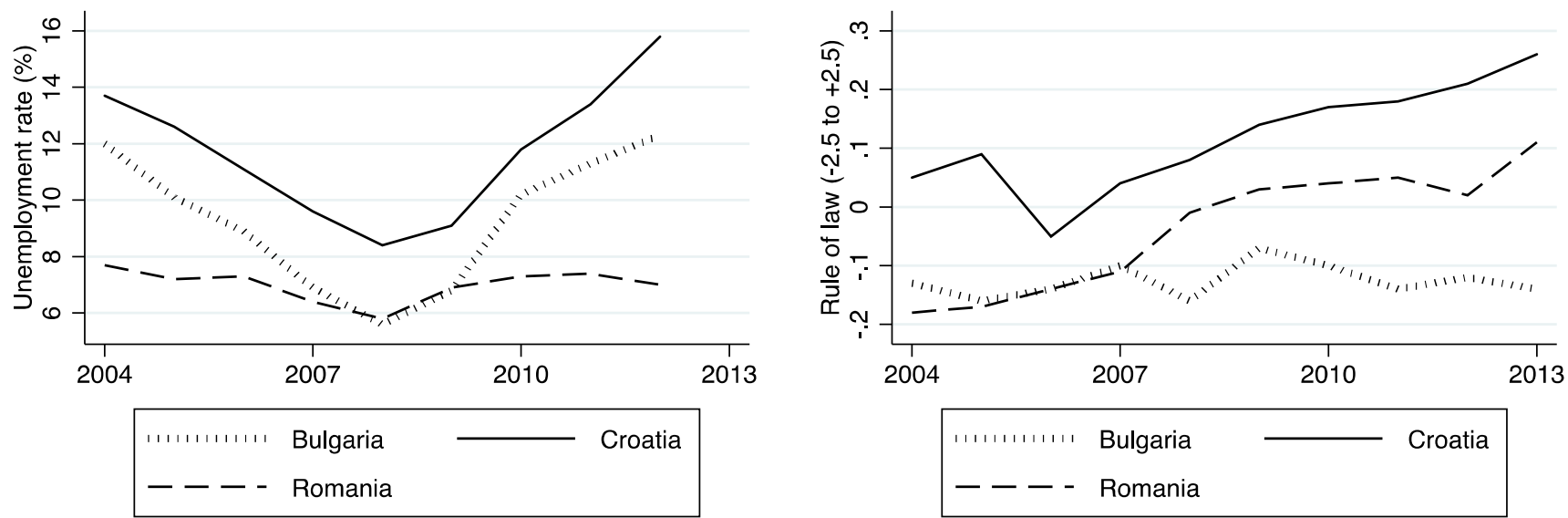

Source: Authors' estimation using World Development Indicators for GDP per capita, unemployment and inflation; Authors' estimation using Worldwide Governance Indicators for the Rule of Law Variable.

Note: The unemployment data are for 2004-2012. 
Figure 3: Life Satisfaction Trends in Bulgaria, Romania, and Croatia, 2006-2008

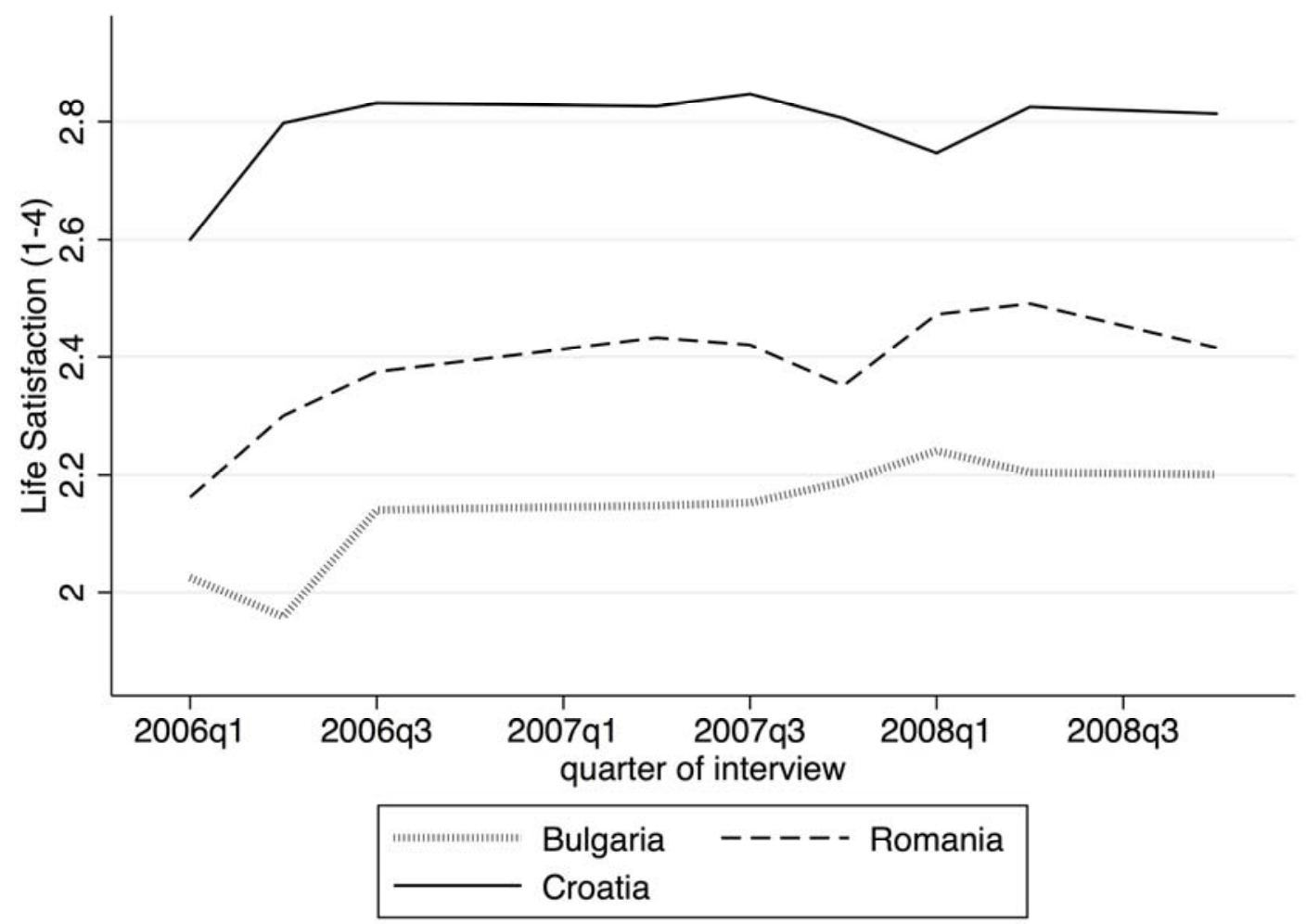

Source: Authors' estimation using Eurobarometer data 
Table 1: Life Satisfaction and Socio-Demographic Variables, Summary Statistics, 2006-2008

\begin{tabular}{|c|c|c|c|c|c|c|c|c|c|}
\hline & \multicolumn{3}{|c|}{ Bulgaria Before } & \multicolumn{3}{|c|}{ Romania Before } & \multicolumn{3}{|c|}{ Croatia Before } \\
\hline & Obs. & Mean & Std. Dev. & Obs. & Mean & Std. Dev. & Obs. & Mean & Std. Dev. \\
\hline Life Satisfaction (1-4) & 1,954 & 2.059 & 0.789 & 1,903 & 2.337 & 0.775 & 1,926 & 2.810 & 0.801 \\
\hline Age & 1,954 & 46.961 & 17.691 & 1,903 & 45.468 & 17.457 & 1,926 & 45.070 & 18.348 \\
\hline Male $(1=$ Yes $)$ & 1,954 & 0.467 & 0.499 & 1,903 & 0.482 & 0.500 & 1,926 & 0.433 & 0.496 \\
\hline Married or in Civil Partnership (1=Yes) & 1,954 & 0.701 & 0.458 & 1,903 & 0.641 & 0.480 & 1,926 & 0.599 & 0.490 \\
\hline Employed $(1=$ Yes $)$ & 1,954 & 0.459 & 0.498 & 1,903 & 0.480 & 0.500 & 1,926 & 0.422 & 0.494 \\
\hline Household Size & 1,954 & 3.061 & 1.571 & 1,903 & 2.632 & 1.369 & 1,926 & 3.153 & 1.618 \\
\hline \multicolumn{10}{|l|}{ Age at Which Stopped Education } \\
\hline No Education & 1,954 & 0.015 & 0.123 & 1,903 & 0.000 & 0.000 & 1,926 & 0.031 & 0.174 \\
\hline 15 Years or Younger & 1,954 & 0.197 & 0.397 & 1,903 & 0.214 & 0.410 & 1,926 & 0.173 & 0.378 \\
\hline 16-19 Years & 1,954 & 0.494 & 0.500 & 1,903 & 0.455 & 0.498 & 1,926 & 0.471 & 0.499 \\
\hline 20 Years or Older & 1,954 & 0.237 & 0.425 & 1,903 & 0.239 & 0.427 & 1,926 & 0.205 & 0.403 \\
\hline Still Studying & 1,954 & 0.057 & 0.232 & 1,903 & 0.092 & 0.290 & 1,926 & 0.120 & 0.326 \\
\hline Large Town $(1=$ Yes $)$ & 1,954 & 0.450 & 0.498 & 1,903 & 0.276 & 0.447 & 1,926 & 0.216 & 0.412 \\
\hline Child in Household (1=Yes) & 1,954 & 0.276 & 0.447 & 1,903 & 0.261 & 0.439 & 1,926 & 0.307 & 0.461 \\
\hline Wealth Index $($ Min $=0$, Max $=9)$ & 1,954 & 4.020 & 1.891 & 1,903 & 3.874 & 2.079 & 1,926 & 6.061 & 2.289 \\
\hline \multirow[t]{3}{*}{ Trust in the EU $(1=$ Yes $)$} & 1,555 & 0.712 & 0.453 & 1,654 & 0.771 & 0.420 & 1,683 & 0.407 & 0.491 \\
\hline & \multicolumn{3}{|c|}{ Bulgaria After } & \multicolumn{3}{|c|}{ Romania After } & \multicolumn{3}{|c|}{ Croatia After } \\
\hline & Obs. & Mean & Std. Dev. & Obs. & Mean & Std. Dev. & Obs. & Mean & Std. Dev. \\
\hline Life Satisfaction (1-4) & 3,783 & 2.186 & 0.802 & 3,957 & 2.429 & 0.763 & 3,670 & 2.817 & 0.782 \\
\hline Age & 3,783 & 48.317 & 17.771 & 3,957 & 45.379 & 17.411 & 3,670 & 46.719 & 18.005 \\
\hline Male $(1=\mathrm{Yes})$ & 3,783 & 0.451 & 0.498 & 3,957 & 0.481 & 0.500 & 3,670 & 0.416 & 0.493 \\
\hline Married or in Civil Partnership (1=Yes) & 3,783 & 0.680 & 0.466 & 3,957 & 0.676 & 0.468 & 3,670 & 0.618 & 0.486 \\
\hline Employed $(1=$ Yes $)$ & 3,783 & 0.477 & 0.500 & 3,957 & 0.514 & 0.500 & 3,670 & 0.428 & 0.495 \\
\hline Household Size & 3,783 & 3.022 & 1.580 & 3,957 & 2.776 & 1.406 & 3,670 & 3.088 & 1.571 \\
\hline \multicolumn{10}{|l|}{ Age at Which Stopped Education } \\
\hline No Education & 3,783 & 0.004 & 0.065 & 3,957 & 0.002 & 0.048 & 3,670 & 0.000 & 0.000 \\
\hline 15 Years or Younger & 3,783 & 0.173 & 0.378 & 3,957 & 0.182 & 0.386 & 3,670 & 0.205 & 0.404 \\
\hline 16-19 Years & 3,783 & 0.479 & 0.500 & 3,957 & 0.463 & 0.499 & 3,670 & 0.494 & 0.500 \\
\hline 20 Years or Older & 3,783 & 0.273 & 0.446 & 3,957 & 0.258 & 0.437 & 3,670 & 0.207 & 0.405 \\
\hline Still Studying & 3,783 & 0.071 & 0.256 & 3,957 & 0.094 & 0.292 & 3,670 & 0.093 & 0.291 \\
\hline Large Town $(1=$ Yes $)$ & 3,783 & 0.446 & 0.497 & 3,957 & 0.332 & 0.471 & 3,670 & 0.230 & 0.421 \\
\hline Child in Household ( $1=\mathrm{Yes})$ & 3,783 & 0.265 & 0.441 & 3,957 & 0.266 & 0.442 & 3,670 & 0.316 & 0.465 \\
\hline Wealth Index (Min=0, Max=9) & 3,783 & 4.546 & 2.058 & 3,957 & 4.363 & 2.171 & 3,670 & 6.381 & 2.241 \\
\hline Trust in the EU $(1=\mathrm{Yes})$ & 3,003 & 0.742 & 0.438 & 3,462 & 0.751 & 0.432 & 3,289 & 0.380 & 0.485 \\
\hline
\end{tabular}

Source Eurobarometer, 2006-2008

Notes: The table shows the number of observations, means, and standard deviations for each variable and for each country. The means of the binary variables show

the proportion of non-missing responses. The wealth index variable sums the total number of household durables (such as a car, a TV, a computer, and others). 
Table 2: The Effects of Joining the EU on Life Satisfaction in Bulgaria and Romania, Baseline Results

\begin{tabular}{|c|c|c|c|c|c|c|}
\hline \multirow{3}{*}{ EU-2 Country $(1=\mathrm{Yes})$} & \multirow[t]{2}{*}{ (1) } & $(2)$ & \multirow[t]{2}{*}{ (3) } & \multirow[t]{2}{*}{ (4) } & (5) & \multirow[t]{2}{*}{ (6) } \\
\hline & & eatment: Bulgaria & & & Treatment: Romania & \\
\hline & $-0.752 * * *$ & $-0.746^{* * *}$ & $-0.581 * * *$ & $-0.473^{* * *}$ & $-0.469 * * *$ & $-0.318^{* * *}$ \\
\hline & $(0.026)$ & $(0.025)$ & $(0.026)$ & $(0.025)$ & $(0.024)$ & $(0.025)$ \\
\hline \multirow[t]{2}{*}{ 2007Q2 and After (1=Yes) } & 0.007 & 0.079 & 0.047 & 0.007 & $0.249^{* * *}$ & $0.214 * * *$ \\
\hline & $(0.022)$ & $(0.056)$ & $(0.055)$ & $(0.022)$ & $(0.080)$ & $(0.078)$ \\
\hline \multirow[t]{2}{*}{ EU-2×2007Q2 } & $0.120^{* * *}$ & $0.086^{* * *}$ & $0.076^{* *}$ & $0.085^{* * *}$ & 0.044 & 0.045 \\
\hline & $(0.031)$ & $(0.030)$ & $(0.029)$ & $(0.031)$ & $(0.029)$ & $(0.029)$ \\
\hline Individual Controls & $\mathrm{N}$ & $\mathrm{Y}$ & Y & $\mathrm{N}$ & $\mathrm{Y}$ & Y \\
\hline Individual Controls + Wealth Index & $\mathrm{N}$ & $\mathrm{N}$ & $\mathrm{Y}$ & $\mathrm{N}$ & $\mathrm{N}$ & $\mathrm{Y}$ \\
\hline Quarter of Interview Dummies & $\mathrm{N}$ & $\mathrm{Y}$ & Y & $\mathrm{N}$ & $\mathrm{Y}$ & $\mathrm{Y}$ \\
\hline Observations & 11,333 & 11,333 & 11,333 & 11,456 & 11,456 & 11,456 \\
\hline Adj. $\mathrm{R}^{2}$ & 0.154 & 0.259 & 0.283 & 0.068 & 0.164 & 0.187 \\
\hline
\end{tabular}

Sources: Author's estimation using Eurobarometer, 2006-2008

Notes: The dependent variable in all models is life satisfaction (on a scale of 1-4). Robust standard errors in parentheses. The treatment variable is the interaction (EU×(after Q2, 2007)). The control country in all regressions is Croatia. The EU-2 Country dummy variable takes the value of 1 for Bulgaria in Columns (1)-(3) and takes the value of 1 for Romania in Models (4)-(6). The individual controls are age, age squared, gender, an indicator for whether the respondent is married or in a civil partnership, married $\times$ gender interaction, employment status indicator, household size, household size squared, whether there are any children in the household, an indicator for a large or small town, and age-education categories (age at which the respondent stopped her full-time education): no education, still in school, 15 years or younger, 20 years or older; the reference group is 16-19 years.

Models (3) and (6) include an additional wealth index control, which sums the total number of household durables (such as a car, a TV, a computer, and others). All regressions include quarter of interview dummies.

${ }^{* * *} \mathrm{p}<0.01,{ }^{* *} \mathrm{p}<0.05,{ }^{*} \mathrm{p}<0.1$ 
Table 3: The Effects of Joining the EU on Life Satisfaction in Bulgaria and Romania, Yearly Interactions

\begin{tabular}{|c|c|c|c|c|}
\hline \multirow[b]{3}{*}{ EU-2 Country (1=Yes) } & (1) & (2) & (3) & (4) \\
\hline & \multicolumn{2}{|c|}{ Bulgaria } & \multicolumn{2}{|c|}{ Romania } \\
\hline & $\begin{array}{c}-0.751 * * * \\
(0.036)\end{array}$ & $\begin{array}{c}-0.785^{* * *} \\
(0.034)\end{array}$ & $\begin{array}{c}-0.473^{* * *} \\
(0.036)\end{array}$ & $\begin{array}{c}-0.490 * * * \\
(0.035)\end{array}$ \\
\hline \multicolumn{5}{|l|}{ Before } \\
\hline EU-2×2006Q1 & $\begin{array}{c}0.176 \\
(0.122)\end{array}$ & $\begin{array}{c}0.163 \\
(0.117)\end{array}$ & $\begin{array}{c}0.036 \\
(0.166)\end{array}$ & $\begin{array}{l}-0.087 \\
(0.155)\end{array}$ \\
\hline EU-2×2006Q2 & $\begin{array}{c}-0.088^{*} \\
(0.053)\end{array}$ & $\begin{array}{l}-0.038 \\
(0.049)\end{array}$ & $\begin{array}{l}-0.024 \\
(0.051)\end{array}$ & $\begin{array}{c}0.002 \\
(0.048)\end{array}$ \\
\hline EU-2×2006Q3 & $\begin{array}{c}0.059 \\
(0.051)\end{array}$ & $\begin{array}{l}0.091 * \\
(0.048)\end{array}$ & $\begin{array}{c}0.017 \\
(0.051)\end{array}$ & $\begin{array}{c}0.028 \\
(0.048)\end{array}$ \\
\hline \multicolumn{5}{|l|}{ After } \\
\hline EU-2×2007Q2 & $\begin{array}{c}0.072 \\
(0.050)\end{array}$ & $\begin{array}{c}0.091 * \\
(0.047)\end{array}$ & $\begin{array}{c}0.080 \\
(0.050)\end{array}$ & $\begin{array}{c}0.080^{*} \\
(0.047)\end{array}$ \\
\hline EU-2×2007Q3 & $\begin{array}{c}0.056 \\
(0.063)\end{array}$ & $\begin{array}{c}0.093 \\
(0.060)\end{array}$ & $\begin{array}{c}0.047 \\
(0.064)\end{array}$ & $\begin{array}{c}0.051 \\
(0.061)\end{array}$ \\
\hline EU-2×2007Q4 & $\begin{array}{c}0.133^{* *} \\
(0.063)\end{array}$ & $\begin{array}{c}0.161^{* * *} \\
(0.060)\end{array}$ & $\begin{array}{c}0.019 \\
(0.062)\end{array}$ & $\begin{array}{c}0.040 \\
(0.059)\end{array}$ \\
\hline EU-2×2008Q1 & $\begin{array}{c}0.245^{* * *} \\
(0.072)\end{array}$ & $\begin{array}{c}0.197 * * * \\
(0.070)\end{array}$ & $\begin{array}{c}0.199 * * * \\
(0.072)\end{array}$ & $\begin{array}{c}0.145^{* *} \\
(0.071)\end{array}$ \\
\hline EU-2×2008Q2 & $\begin{array}{c}0.130^{* *} \\
(0.062)\end{array}$ & $\begin{array}{c}0.142 * * \\
(0.058)\end{array}$ & $\begin{array}{c}0.139 * * \\
(0.056)\end{array}$ & $\begin{array}{c}0.110^{* *} \\
(0.053)\end{array}$ \\
\hline EU-2×2008Q4 & $\begin{array}{c}0.138^{* * *} \\
(0.051)\end{array}$ & $\begin{array}{c}0.122^{* *} \\
(0.048)\end{array}$ & $\begin{array}{c}0.076 \\
(0.051)\end{array}$ & $\begin{array}{c}0.012 \\
(0.048)\end{array}$ \\
\hline Individual Controls & $\mathrm{N}$ & $\mathrm{Y}$ & $\mathrm{N}$ & $\mathrm{Y}$ \\
\hline Individual Controls + Wealth Index & $\mathrm{N}$ & $\mathrm{N}$ & $\mathrm{N}$ & $\mathrm{N}$ \\
\hline Quarter of Interview Dummies & Y & Y & Y & Y \\
\hline Observations & 13,286 & 13,286 & 13,365 & 13,365 \\
\hline Adj. R-squared & 0.160 & 0.264 & 0.071 & 0.169 \\
\hline
\end{tabular}

Sources: Author's estimation using Eurobarometer, 2005Q4-2008

Notes: The dependent variable in all models is life satisfaction (on a scale of 1-4). Robust standard errors in parentheses. The omitted category for the interactions is EU-2×2005Q4.The control country in all regressions is Croatia. The EU-2 Country dummy variable takes the value of 1 for Bulgaria in Columns (1)-(3) and takes the value of 1 for Romania in Models (4)-(6). The individual controls are age, age squared, gender, an indicator for whether the respondent is married or in a civil partnership, married $\times$ gender interaction, employment status indicator, household size, household size squared, whether there are any children in the household, an indicator for a large or small town, and age-education categories (age at which the respondent stopped her full-time education): no education, still in school, 15 years or younger, 20 years or older; the reference group is $16-$ 19 years.

*** $\mathrm{p}<0.01, * * \mathrm{p}<0.05, * \mathrm{p}<0.1$ 
Table 4: Joining the EU and Life Satisfaction, Heterogeneous Treatment Effects, By Age Groups

\begin{tabular}{|c|c|c|c|c|c|c|}
\hline \multicolumn{7}{|c|}{ By Age Groups } \\
\hline & (1) & $(2)$ & (3) & (4) & (5) & (6) \\
\hline & \multicolumn{3}{|c|}{ Treatment: Bulgaria } & \multicolumn{3}{|c|}{ Treatment: Romania } \\
\hline & Under 35 & Ages 36-60 & Over 60 & Under 35 & Ages 36-60 & Over 60 \\
\hline \multirow[t]{2}{*}{ EU-2 Country (1=Yes) } & $-0.716^{* * *}$ & $-0.773 * * *$ & $-0.718^{* * *}$ & $-0.506^{* * *}$ & $-0.403 * * *$ & $-0.546 * * *$ \\
\hline & $(0.043)$ & $(0.039)$ & $(0.053)$ & $(0.039)$ & $(0.038)$ & $(0.056)$ \\
\hline \multirow[t]{2}{*}{ 2007Q2 and After (1=Yes) } & 0.029 & 0.087 & 0.115 & $0.391 * * *$ & $0.202^{*}$ & 0.001 \\
\hline & $(0.095)$ & $(0.076)$ & $(0.099)$ & $(0.143)$ & $(0.115)$ & $(0.148)$ \\
\hline \multirow[t]{2}{*}{ EU-2×2007Q2 } & $0.152^{* * *}$ & $0.122^{* * *}$ & -0.066 & 0.036 & 0.017 & 0.091 \\
\hline & $(0.051)$ & $(0.046)$ & $(0.064)$ & $(0.048)$ & $(0.045)$ & $(0.067)$ \\
\hline Individual Controls & $\mathrm{Y}$ & Y & $\mathrm{Y}$ & Y & $\mathrm{Y}$ & $\mathrm{Y}$ \\
\hline Individual Controls + Wealth Index & $\mathrm{N}$ & $\mathrm{N}$ & $\mathrm{N}$ & $\mathrm{N}$ & $\mathrm{N}$ & $\mathrm{N}$ \\
\hline Quarter of Interview Dummies & Y & Y & Y & Y & Y & Y \\
\hline Observations & 3,481 & 4,889 & 2,963 & 3,812 & 4,984 & 2,660 \\
\hline Adj. $\mathrm{R}^{2}$ & 0.247 & 0.212 & 0.211 & 0.143 & 0.120 & 0.134 \\
\hline
\end{tabular}

Sources: Author's estimation using Eurobarometer, 2006-2008

Notes: The dependent variable in all models is life satisfaction (on a scale of 1-4). Robust standard errors in parentheses. The treatment variable is the interaction $(\mathrm{EU} \times($ after Q2, 2007)). The control country in all regressions is Croatia. The EU-2 Country dummy variable takes the value of 1 for Bulgaria in Columns (1)-(3) and takes the value of 1 for Romania in Models (4)-(6). The individual controls are age, age squared, gender, an indicator for whether the respondent is married or in a civil partnership, married $\times$ gender interaction, employment status indicator, household size, household size squared, whether there are any children in the household, an indicator for a large or small town, and age-education categories (age at which the respondent stopped her full-time education): no education, still in school, 15 years or younger, 20 years or older; the reference group is 16-19 years. All regressions include quarter of interview dummies.

*** $\mathrm{p}<0.01,{ }^{* *} \mathrm{p}<0.05, * \mathrm{p}<0.1$ 
Table 5: Joining the EU and Life Satisfaction, Heterogeneous Treatment Effects, By Employment Status

\begin{tabular}{|c|c|c|c|c|}
\hline \multicolumn{5}{|c|}{ Panel A: By Employment Status } \\
\hline & (1) & $(2)$ & (3) & (4) \\
\hline & \multicolumn{2}{|c|}{ Treatment: Bulgaria } & \multicolumn{2}{|c|}{ Treatment: Romania } \\
\hline & Employed & Not Employed & Employed & Not Employed \\
\hline \multirow[t]{2}{*}{ EU-2 Country (1=Yes) } & $-0.754 * * *$ & $-0.735^{* * *}$ & $-0.461 * * *$ & $-0.481 * * *$ \\
\hline & $(0.036)$ & $(0.035)$ & $(0.034)$ & $(0.034)$ \\
\hline \multirow[t]{2}{*}{ 2007Q2 and After (1=Yes) } & 0.050 & 0.087 & 0.055 & $0.335^{* * *}$ \\
\hline & $(0.072)$ & $(0.070)$ & $(0.091)$ & $(0.117)$ \\
\hline \multirow[t]{2}{*}{ EU-2×2007Q2 } & $0.192^{* * *}$ & -0.003 & $0.082 * *$ & 0.016 \\
\hline & $(0.043)$ & $(0.042)$ & $(0.041)$ & $(0.041)$ \\
\hline Individual Controls & $\mathrm{Y}$ & $\mathrm{Y}$ & $\mathrm{Y}$ & $\mathrm{Y}$ \\
\hline Individual Controls + Wealth Index & $\mathrm{N}$ & $\mathrm{N}$ & $\mathrm{N}$ & $\mathrm{N}$ \\
\hline Quarter of Interview Dummies & $\mathrm{Y}$ & $\mathrm{Y}$ & Y & Y \\
\hline Observations & 5,084 & 6,249 & 5,331 & 6,125 \\
\hline Adj. $\mathrm{R}^{2}$ & 0.198 & 0.287 & 0.114 & 0.187 \\
\hline \multicolumn{5}{|c|}{ Panel B: By Unemployment Status } \\
\hline & $(5)$ & $(6)$ & $(7)$ & $(8)$ \\
\hline & \multicolumn{2}{|c|}{ Treatment: Bulgaria } & \multicolumn{2}{|c|}{ Treatment: Romania } \\
\hline & Unemployed & Not Unemployed & Unemployed & Not Unemployed \\
\hline \multirow{2}{*}{ EU-2 Country (1=Yes) } & $-0.857 * * *$ & $-0.721 * * *$ & $-0.404 * * *$ & $-0.479 * * *$ \\
\hline & $(0.077)$ & $(0.026)$ & $(0.092)$ & $(0.025)$ \\
\hline \multirow[t]{2}{*}{ 2007Q2 and After (1=Yes) } & 0.019 & 0.084 & $0.798^{* *}$ & $0.181 * *$ \\
\hline & $(0.146)$ & $(0.054)$ & $(0.347)$ & $(0.079)$ \\
\hline \multirow[t]{2}{*}{ EU-2×2007Q2 } & 0.111 & $0.084 * * *$ & 0.063 & 0.045 \\
\hline & $(0.092)$ & $(0.032)$ & $(0.112)$ & $(0.031)$ \\
\hline Individual Controls & $\mathrm{Y}$ & $\mathrm{Y}$ & $\mathrm{Y}$ & $\mathrm{Y}$ \\
\hline Individual Controls + Wealth Index & $\mathrm{N}$ & $\mathrm{N}$ & $\mathrm{N}$ & $\mathrm{N}$ \\
\hline Quarter of Interview Dummies & $\mathrm{Y}$ & Y & Y & Y \\
\hline Observations & 1,365 & 9,968 & 1,013 & 10,443 \\
\hline Adj. $\mathrm{R}^{2}$ & 0.274 & 0.251 & 0.140 & 0.166 \\
\hline \multicolumn{5}{|c|}{ Panel C: By Retirement Status } \\
\hline & $(9)$ & $(10)$ & (11) & $(12)$ \\
\hline & \multicolumn{2}{|c|}{ Treatment: Bulgaria } & \multicolumn{2}{|c|}{ Treatment: Romania } \\
\hline & Retired & Not Retired & Retired & Not Retired \\
\hline \multirow[t]{2}{*}{ EU-2 Country (1=Yes) } & $-0.747 * * *$ & $-0.746^{* * *}$ & $-0.530 * * *$ & $-0.440 * * *$ \\
\hline & $(0.047)$ & $(0.030)$ & $(0.049)$ & $(0.028)$ \\
\hline \multirow[t]{2}{*}{ 2007Q2 and After (1=Yes) } & 0.073 & 0.095 & $0.361 * *$ & $0.169^{*}$ \\
\hline & $(0.090)$ & $(0.063)$ & $(0.155)$ & $(0.092)$ \\
\hline \multirow[t]{2}{*}{ EU-2×2007Q2 } & -0.075 & $0.158^{* * *}$ & 0.047 & 0.044 \\
\hline & $(0.057)$ & $(0.035)$ & $(0.059)$ & $(0.034)$ \\
\hline Individual Controls & $\mathrm{Y}$ & $\mathrm{Y}$ & $\mathrm{Y}$ & $\mathrm{Y}$ \\
\hline Individual Controls + Wealth Index & $\mathrm{N}$ & $\mathrm{N}$ & $\mathrm{N}$ & $\mathrm{N}$ \\
\hline Quarter of Interview Dummies & $\mathrm{Y}$ & Y & Y & $\mathrm{Y}$ \\
\hline Observations & 3,456 & 7,877 & 3,240 & 8,216 \\
\hline Adj. $\mathrm{R}^{2}$ & 0.229 & 0.238 & 0.143 & 0.140 \\
\hline
\end{tabular}

Sources: Author's estimation using Eurobarometer, 2006-2008

Notes: The dependent variable in all models is life satisfaction (on a scale of 1-4). Robust standard errors in parentheses. The treatment variable is the interaction $(\mathrm{EU} \times($ after Q2, 2007)). The control country in all regressions is Croatia. The EU-2 Country dummy variable takes the value of 1 for Bulgaria in Columns (1)-(3) and takes the value of 1 for Romania in Models (4)-(6). The individual controls are age, age squared, gender, an indicator for whether the respondent is married or in a civil partnership, married $\times$ gender interaction, household size, household size squared, whether there are any children in the household, an indicator for a large or small town, and ageeducation categories (age at which the respondent stopped her full-time education): no education, still in school, 15 years or younger, 20 years or older; the reference group is 16-19 years. Note that the regressions exclude employment status indicators. All regressions include quarter of interview dummies.

$* * * \mathrm{p}<0.01, * * \mathrm{p}<0.05, * \mathrm{p}<0.1$ 
Table 6: Joining the EU and Life Satisfaction, Heterogeneous Treatment Effects, By Education

\begin{tabular}{|c|c|c|c|c|c|c|c|c|}
\hline \multicolumn{9}{|c|}{ By Age At Which Stopped Full Time Education } \\
\hline & (1) & $(2)$ & (3) & (4) & \multirow{2}{*}{\multicolumn{4}{|c|}{$\stackrel{(6)}{\text { Treatment: Romania }}$}} \\
\hline & \multicolumn{4}{|c|}{ Treatment: Bulgaria } & & & & \\
\hline & $\begin{array}{c}15 \text { Years or } \\
\text { Younger }\end{array}$ & 16-19 Years & $20+$ Years & Still Studying & $\begin{array}{c}15 \text { Years or } \\
\text { Younger }\end{array}$ & 16-19 Years & $20+$ Years & Still Studying \\
\hline EU-2 Country (1=Yes) & $\begin{array}{c}-0.717 * * * \\
(0.060)\end{array}$ & $\begin{array}{c}-0.789 * * * \\
(0.036)\end{array}$ & $\begin{array}{c}-0.747 * * * \\
(0.051)\end{array}$ & $\begin{array}{c}-0.461 * * * \\
(0.089)\end{array}$ & $\begin{array}{c}-0.407 * * * \\
(0.059)\end{array}$ & $\begin{array}{c}-0.519 * * * \\
(0.035)\end{array}$ & $\begin{array}{c}-0.434 * * * \\
(0.050)\end{array}$ & $\begin{array}{c}-0.419^{* * *} \\
(0.069)\end{array}$ \\
\hline 2007Q2 and After (1=Yes) & $\begin{array}{l}0.207^{*} \\
(0.124)\end{array}$ & $\begin{array}{c}0.054 \\
(0.070)\end{array}$ & $\begin{array}{c}0.060 \\
(0.102)\end{array}$ & $\begin{array}{c}0.185 \\
(0.236)\end{array}$ & $\begin{array}{c}0.403^{* *} \\
(0.196)\end{array}$ & $\begin{array}{l}0.176^{*} \\
(0.102)\end{array}$ & $\begin{array}{c}0.226 \\
(0.148)\end{array}$ & $\begin{array}{c}0.379 \\
(0.241)\end{array}$ \\
\hline EU-2×2007Q2 & $\begin{array}{l}-0.046 \\
(0.073)\end{array}$ & $\begin{array}{c}0.154 * * * \\
(0.043)\end{array}$ & $\begin{array}{c}0.079 \\
(0.061)\end{array}$ & $\begin{array}{l}-0.003 \\
(0.101)\end{array}$ & $\begin{array}{l}-0.015 \\
(0.071)\end{array}$ & $\begin{array}{c}0.126^{* * *} \\
(0.043)\end{array}$ & $\begin{array}{l}-0.027 \\
(0.059)\end{array}$ & $\begin{array}{l}-0.119 \\
(0.086)\end{array}$ \\
\hline Individual Controls & $\mathrm{Y}$ & $\mathrm{Y}$ & $\mathrm{Y}$ & $\mathrm{Y}$ & $\mathrm{Y}$ & $\mathrm{Y}$ & $\mathrm{Y}$ & $\mathrm{Y}$ \\
\hline Individual Controls + Wealth Index & $\mathrm{N}$ & $\mathrm{N}$ & $\mathrm{N}$ & $\mathrm{N}$ & $\mathrm{N}$ & $\mathrm{N}$ & $\mathrm{N}$ & $\mathrm{N}$ \\
\hline Quarter of Interview Dummies & $\mathrm{Y}$ & Y & Y & $\mathrm{Y}$ & $\mathrm{Y}$ & $\mathrm{Y}$ & Y & $\mathrm{Y}$ \\
\hline Observations & 2,124 & 5,499 & 2,651 & 953 & 2,214 & 5,420 & 2,629 & 1,124 \\
\hline Adj. $\mathrm{R}^{2}$ & 0.197 & 0.211 & 0.213 & 0.102 & 0.088 & 0.112 & 0.120 & 0.131 \\
\hline
\end{tabular}

Adj. $\mathrm{R}^{2} \mathrm{0.197}$

Notes: The dependent variable in all models is life satisfaction (on a scale of 1-4). Robust standard errors in parentheses. The treatment variable is the interaction (EU $\times($ after Q2, 2007)). The control country in all regressions is Croatia. The EU-2 Country dummy variable takes the value of 1 for Bulgaria in Columns (1)-(3) and takes the value of 1 for Romania in Models (4)-(6). The individual controls are age, age squared, gender, an indicator for whether the respondent is married or in a civil partnership, married $\times$ gender interaction, employment status indicator, household size, household size squared, whether there are any children in the household, an indicator for a large or small town. The regressions exclude indicators for the age at which the respondent stopped full time education. All regressions include quarter of interview dummies.

$* * * \mathrm{p}<0.01, * * \mathrm{p}<0.05, * \mathrm{p}<0.1$ 
Table 7: The Effects of Joining the EU on Trust Towards the EU in Bulgaria and Romania

\begin{tabular}{|c|c|c|c|c|c|c|}
\hline & \multicolumn{2}{|c|}{ Treatment: Bulgaria } & (3) & \multicolumn{2}{|c|}{ Treatment: Romania } & (6) \\
\hline EU-2 Country (1=Yes) & $\begin{array}{c}0.305^{* * *} \\
(0.017)\end{array}$ & $\begin{array}{c}0.292^{* * *} \\
(0.017)\end{array}$ & $\begin{array}{c}0.322^{* * *} \\
(0.018)\end{array}$ & $\begin{array}{c}0.364^{* * *} \\
(0.016)\end{array}$ & $\begin{array}{c}0.362^{* * *} \\
(0.016)\end{array}$ & $\begin{array}{c}0.390^{* * *} \\
(0.017)\end{array}$ \\
\hline 2007Q2 and After (1=Yes) & $\begin{array}{c}-0.027^{*} \\
(0.015)\end{array}$ & $\begin{array}{l}-0.069^{*} \\
(0.038)\end{array}$ & $\begin{array}{c}-0.074 * * \\
(0.037)\end{array}$ & $\begin{array}{l}-0.027^{*} \\
(0.015)\end{array}$ & $\begin{array}{c}0.065 \\
(0.059)\end{array}$ & $\begin{array}{c}0.058 \\
(0.059)\end{array}$ \\
\hline EU-2×2007Q2 & $\begin{array}{c}0.057 * * * \\
(0.020)\end{array}$ & $\begin{array}{c}0.046 * * \\
(0.021)\end{array}$ & $\begin{array}{c}0.044 * * \\
(0.021)\end{array}$ & $\begin{array}{c}0.007 \\
(0.019)\end{array}$ & $\begin{array}{l}-0.000 \\
(0.019)\end{array}$ & $\begin{array}{l}-0.000 \\
(0.019)\end{array}$ \\
\hline Individual Controls & $\mathrm{N}$ & Y & Y & $\mathrm{N}$ & Y & Y \\
\hline Individual Controls + Wealth Index & $\mathrm{N}$ & $\mathrm{N}$ & $\mathrm{Y}$ & $\mathrm{N}$ & $\mathrm{N}$ & $\mathrm{Y}$ \\
\hline Quarter of Interview Dummies & $\mathrm{N}$ & $\mathrm{Y}$ & Y & $\mathrm{N}$ & Y & Y \\
\hline Observations & 9,530 & 9,530 & 9,530 & 10,088 & 10,088 & 10,088 \\
\hline Adj. $R^{2}$ & 0.119 & 0.138 & 0.140 & 0.139 & 0.151 & 0.152 \\
\hline
\end{tabular}

Sources: Authors' estimation using Eurobarometer, 2006-2008

Notes: The dependent variable in all models is EU trust (1=Yes). Robust standard errors in parentheses. The treatment variable is the interaction (EU $\times($ after Q2, 2007)). The control country in all regressions is Croatia. The EU-2 Country dummy variable takes the value of 1 for Bulgaria in Columns (1)-(3) and takes the value of 1 for Romania in Models (4)-(6).

The individual controls are age, age squared, gender, an indicator for whether the respondent is married or in a civil partnership, married $\times$ gender interaction, employment status

indicator, household size, household size squared, whether there are any children in the household, an indicator for a large or small town, and age-education categories (age at which the respondent stopped her full-time education): no education, still in school, 15 years or younger, 20 years or older; the reference group is 16-19 years. Models (3) and (6) include an additional wealth index control, which sums the total number of household durables (such as a car, a TV, a computer, and others). All regressions include quarter of interview dummies. All regressions are estimated using linear probability models.

$* * * \mathrm{p}<0.01,{ }^{* *} \mathrm{p}<0.05,{ }^{*} \mathrm{p}<0.1$ 
Table 8: The Effects of Joining the EU on Life Satisfaction in Bulgaria and Romania, Placebo Tests

\begin{tabular}{|c|c|c|c|c|c|c|}
\hline \multicolumn{7}{|c|}{ Panel A: 2005Q1 - 2008Q4, Fake Treatment: 2005Q4 and after } \\
\hline & (1) & (2) & (3) & (4) & (5) & (6) \\
\hline & \multicolumn{3}{|c|}{ Treatment: Bulgaria } & \multicolumn{3}{|c|}{ Treatment: Romania } \\
\hline EU-2 Country (1=Yes) & $-0.696 * * *$ & $-0.713^{* * *}$ & $-0.512^{* * *}$ & $-0.314 * * *$ & $-0.314 * * *$ & $-0.228^{* * *}$ \\
\hline & $(0.026)$ & $(0.024)$ & $(0.036)$ & $(0.026)$ & $(0.024)$ & $(0.036)$ \\
\hline \multirow[t]{2}{*}{ 2005Q4 and After (1=Yes) } & $-0.046^{* *}$ & $-0.284 * * *$ & $0.106^{* * *}$ & $-0.046^{* *}$ & $-0.461 * * *$ & $0.082 * *$ \\
\hline & $(0.021)$ & $(0.048)$ & $(0.032)$ & $(0.021)$ & $(0.079)$ & $(0.032)$ \\
\hline \multirow[t]{2}{*}{ EU-2×2005Q4 } & 0.012 & 0.004 & -0.018 & $-0.109 * * *$ & $-0.136 * * *$ & -0.061 \\
\hline & $(0.029)$ & $(0.027)$ & $(0.038)$ & $(0.029)$ & $(0.028)$ & $(0.038)$ \\
\hline Individual Controls & $\mathrm{N}$ & $\mathrm{Y}$ & $\mathrm{Y}$ & $\mathrm{N}$ & $\mathrm{Y}$ & $\mathrm{Y}$ \\
\hline Individual Controls + Wealth Index & $\mathrm{N}$ & $\mathrm{N}$ & Y & $\mathrm{N}$ & $\mathrm{N}$ & Y \\
\hline Quarter of Interview Dummies & $\mathrm{N}$ & $\mathrm{Y}$ & Y & $\mathrm{N}$ & $\mathrm{Y}$ & $\mathrm{Y}$ \\
\hline Observations & 17,057 & 17,057 & 13,209 & 17,124 & 17,124 & 13,278 \\
\hline Adj. $\mathrm{R}^{2}$ & 0.157 & 0.268 & 0.284 & 0.064 & 0.174 & 0.188 \\
\hline \multicolumn{7}{|c|}{ Panel A: 2008Q1 - 2009Q2, Fake Treatment: 2009Q1 and after } \\
\hline & $(1)$ & $(2)$ & (3) & (4) & (5) & (6) \\
\hline & \multicolumn{3}{|c|}{ Treatment: Bulgaria } & \multicolumn{3}{|c|}{ Treatment: Romania } \\
\hline EU-2 Country (1=Yes) & $-0.596^{* * *}$ & $-0.631 * * *$ & $-0.504 * * *$ & $-0.360 * * *$ & $-0.414 * * *$ & $-0.271 * * *$ \\
\hline & $(0.026)$ & $(0.026)$ & $(0.027)$ & $(0.025)$ & $(0.024)$ & $(0.026)$ \\
\hline \multirow[t]{2}{*}{ 2005Q4 and After (1=Yes) } & 0.022 & 0.012 & -0.007 & 0.022 & -0.018 & -0.037 \\
\hline & $(0.024)$ & $(0.037)$ & $(0.037)$ & $(0.024)$ & $(0.037)$ & $(0.037)$ \\
\hline \multirow[t]{2}{*}{ EU-2×2005Q4 } & -0.020 & -0.026 & -0.015 & -0.049 & -0.024 & -0.028 \\
\hline & $(0.034)$ & $(0.033)$ & $(0.032)$ & $(0.033)$ & $(0.032)$ & $(0.031)$ \\
\hline Individual Controls & $\mathrm{N}$ & $\mathrm{Y}$ & $\mathrm{Y}$ & $\mathrm{N}$ & $\mathrm{Y}$ & $\mathrm{Y}$ \\
\hline Individual Controls + Wealth Index & $\mathrm{N}$ & $\mathrm{N}$ & $\mathrm{Y}$ & $\mathrm{N}$ & $\mathrm{N}$ & $\mathrm{Y}$ \\
\hline Quarter of Interview Dummies & $\mathrm{N}$ & Y & Y & $\mathrm{N}$ & Y & Y \\
\hline Observations & 9,173 & 9,173 & 9,173 & 9,476 & 9,476 & 9,476 \\
\hline Adj. $\mathrm{R}^{2}$ & 0.125 & 0.220 & 0.239 & 0.057 & 0.139 & 0.162 \\
\hline
\end{tabular}

Sources: Authors' estimation using Eurobarometer, 2006-2008

Notes: The dependent variable in all models is life satisfaction (on a scale of 1-4). Robust standard errors in parentheses. The placebo treatment variable is .the last quarter of 2005 in Panel A; and the first quarter of 2009 in Panel B. The control country in all regressions is Croatia. The EU-2 Country dummy variable takes the value of 1 for Bulgaria in Columns (1)-(3) and takes the value of 1 for Romania in Models (4)-(6). The individual controls are age, age squared, gender, an indicator for whether the respondent is married or in a civil partnership, married $\times$ gender interaction, employment status indicator, household size, household size squared, whether there are any children in the household, an indicator for a large or small town, and age-education categories (age at which the respondent stopped her full-time education): no education, still in school, 15 years or younger, 20 years or older; the reference group is 16-19 years. Models (3) and (6) include an additional wealth index control, which sums the total number of household durables (such as a car, a TV, a computer, and others). All regressions include quarter of interview dummies.

$* * * \mathrm{p}<0.01, * * \mathrm{p}<0.05, * \mathrm{p}<0.1$ 
Table 9: The Effects of Joining the EU on Life Satisfaction in Bulgaria and Romania, Wild Bootstrapped Standard Errors, Eurobarometer 2006-2008

\begin{tabular}{|c|c|c|c|c|c|c|}
\hline \multirow[b]{3}{*}{ EU-2 Country (1=Yes) } & (1) & $(2)$ & (3) & (4) & (5) & (6) \\
\hline & \multicolumn{3}{|c|}{ Treatment: Bulgaria } & \multicolumn{3}{|c|}{ Treatment: Romania } \\
\hline & $\begin{array}{c}-0.752^{* * *} \\
(0.002)\end{array}$ & $\begin{array}{c}-0.746^{* * *} \\
(0.002)\end{array}$ & $\begin{array}{c}-0.581 * * * \\
(0.002)\end{array}$ & $\begin{array}{c}-0.473 * * * \\
(0.002)\end{array}$ & $\begin{array}{c}-0.469 * * * \\
(0.002)\end{array}$ & $\begin{array}{c}-0.318^{* * *} \\
(0.002)\end{array}$ \\
\hline 2007Q2 and After (1=Yes) & $\begin{array}{c}0.007 * * * \\
(0.000)\end{array}$ & $\begin{array}{c}0.079 * * * \\
(0.000)\end{array}$ & $\begin{array}{c}0.047 \\
(0.484)\end{array}$ & $\begin{array}{c}0.007 * * * \\
(0.000)\end{array}$ & $\begin{array}{c}0.249 \\
(0.500)\end{array}$ & $\begin{array}{c}0.214^{* * *} \\
(0.000)\end{array}$ \\
\hline EU-2×2007Q2 & $\begin{array}{c}0.120^{* * *} \\
(0.000)\end{array}$ & $\begin{array}{c}0.086^{* * *} \\
(0.000)\end{array}$ & $\begin{array}{c}0.076^{* * *} \\
(0.000)\end{array}$ & $\begin{array}{c}0.085^{* * *} * \\
(0.000)\end{array}$ & $\begin{array}{c}0.044^{* * *} \\
(0.000)\end{array}$ & $\begin{array}{c}0.045^{* * *} \\
(0.000)\end{array}$ \\
\hline Individual Controls & $\mathrm{N}$ & $\mathrm{Y}$ & $\mathrm{Y}$ & $\mathrm{N}$ & $\mathrm{Y}$ & $\mathrm{Y}$ \\
\hline Individual Controls + Wealth Index & $\mathrm{N}$ & $\mathrm{N}$ & $\mathrm{Y}$ & $\mathrm{N}$ & $\mathrm{N}$ & Y \\
\hline Quarter of Interview Dummies & $\mathrm{N}$ & $\mathrm{Y}$ & $\mathrm{Y}$ & $\mathrm{N}$ & $\mathrm{Y}$ & $\mathrm{Y}$ \\
\hline Observations & 11,333 & 11,333 & 11,333 & 11,456 & 11,456 & 11,456 \\
\hline Adj. $R^{2}$ & 0.154 & 0.259 & 0.283 & 0.068 & 0.164 & 0.187 \\
\hline
\end{tabular}

Sources: Authors estimation using Eurobarometer, 2006-2008

Notes: The dependent variable in all models is life satisfaction (on a scale of 1-4). P-values in parentheses. The treatment variable is the interaction $(\mathrm{EU} \times($ after Q2, 2007)). The control country in all regressions is Croatia. The EU-2 Country dummy variable takes the value of 1 for Bulgaria in Columns (1)-(3) and takes the value of 1 for Romania in Models (4)-(6). The individual controls are age, age squared, gender, an indicator for whether the respondent is married or in a civil partnership, married $\times$ gender interaction, employment status indicator, household size, household size squared, whether there are any children in the household, an indicator for a large or small town, and age-education categories (age at which the respondent stopped her full-time education): no education, still in school, 15 years or younger, 20 years or older; the reference group is 16-19 years. Models (3) and (6) include an additional wealth index control, which sums the total number of household durables (such as a car, a TV, a computer, and others). All regressions include quarter of interview dummies.

$* * * \mathrm{p}<0.01, * * \mathrm{p}<0.05, * \mathrm{p}<0.1$ 


\section{APPENDIX}

Table A1: Joining the EU and Life Satisfaction, Heterogeneous Treatment Effects, By Gender

\begin{tabular}{lcc|cc}
\hline & \multicolumn{2}{c|}{$(1)$} & $(2)$ & \multicolumn{2}{c}{$(4)$} & $(5)$ \\
& \multicolumn{2}{c}{ Treatment: Bulgaria } & \multicolumn{2}{c}{ Treatment: Romania } \\
\cline { 2 - 5 } & Males & Females & Males & Females \\
\hline EU-2 Country (1=Yes) & $-0.710^{* * *}$ & $-0.768^{* * *}$ & $-0.451^{* * *}$ & $-0.487^{* * *}$ \\
& $(0.037)$ & $(0.034)$ & $(0.035)$ & $(0.033)$ \\
$2007 Q 2$ and After (1=Yes) & 0.114 & 0.038 & $0.358^{* * *}$ & 0.097 \\
& $(0.076)$ & $(0.067)$ & $(0.108)$ & $(0.106)$ \\
EU-2×2007Q2 & $0.095^{* *}$ & $0.079 *$ & 0.050 & 0.046 \\
Individual Controls & $(0.045)$ & $(0.040)$ & $(0.043)$ & $(0.040)$ \\
Individual Controls + Wealth Index & $\mathrm{N}$ & $\mathrm{Y}$ & $\mathrm{N}$ & $\mathrm{Y}$ \\
Quarter of Interview Dummies & $\mathrm{N}$ & $\mathrm{N}$ & $\mathrm{N}$ & $\mathrm{N}$ \\
Observations & $\mathrm{N}$ & $\mathrm{Y}$ & $\mathrm{N}$ & $\mathrm{Y}$ \\
Adj. $\mathrm{R}^{2}$ & 4,980 & 6,353 & 5,183 & 6,273 \\
\hline
\end{tabular}

Sources: Authors' estimation using Eurobarometer, 2006-2008

Notes: The dependent variable in all models is life satisfaction (on a scale of 1-4). Robust standard errors in parentheses. The treatment variable is the interaction $(\mathrm{EU} \times($ after $\mathrm{Q} 2,2007))$. The control country in all regressions is Croatia. The EU-2 Country dummy variable takes the value of 1 for Bulgaria in Columns (1)-(2) and takes the value of 1 for Romania in Models (3)-(4). The individual controls are age, age squared, an indicator for whether the respondent is married or in a civil partnership, household size, household size squared, whether there are any children in the household, an indicator for a large or small town, and age-education categories (age at which the respondent stopped her full-time education): no education, still in school, 15 years or younger, 20 years or older; the reference group is 16-19 years. All regressions include quarter of interview dummies.

$* * * \mathrm{p}<0.01, * * \mathrm{p}<0.05, * \mathrm{p}<0.1$ 